US Army Corps

of Engineers ${ }_{\circledast}$

Engineer Research and

Development Center

Estimating Growing-Season Root Zone Soil Moisture from Vegetation Index-Based Evapotranspiration Fraction and Soil Properties in the Northwest Mountain Region, USA

Nawa Raj Pradhan

September 2021 
The U.S. Army Engineer Research and Development Center (ERDC) solves the nation's toughest engineering and environmental challenges. ERDC develops innovative solutions in civil and military engineering, geospatial sciences, water resources, and environmental sciences for the Army, the Department of Defense, civilian agencies, and our nation's public good. Find out more at www.erdc.usace.army.mil.

To search for other technical reports published by ERDC, visit the ERDC online library at https://erdclibrary.on.worldcat.org/discovery. 


\section{Estimating Growing-Season Root Zone Soil Moisture from Vegetation Index-Based Evapotranspiration Fraction and Soil Properties in the Northwest Mountain Region, USA}

Nawa Raj Pradhan

Coastal and Hydraulics Laboratory

U.S. Army Engineer Research and Development Center

3909 Halls Ferry Road

Vicksburg, MS 39180

Final report

Approved for public release; distribution is unlimited. 


\section{Preface}

This study was conducted for the U.S. Army Corps of Engineers (USACE) with funding provided by the U.S. Army Military Engineering Program. Article Processing Charges (APCs) for the publication were supported by the USACE Flood and Coastal Storm Damage Reduction Research and Development Program.

The work was performed by the U.S. Army Engineer Research and Development Center, Coastal and Hydraulics Laboratory (ERDC-CHL). At the time of publication of this paper, the Deputy Director of ERDC-CHL was Mr. Keith Flowers, and the Director was Dr. Ty V. Wamsley.

This article was originally published online in the Hydrological Sciences Journal on 19 May 2019.

The Commander of ERDC was COL Teresa A. Schlosser and the Director was Dr. David W. Pittman.

DISCLAIMER: The contents of this report are not to be used for advertising, publication, or promotional purposes. Citation of trade names does not constitute an official endorsement or approval of the use of such commercial products. All product names and trademarks cited are the property of their respective owners. The findings of this report are not to be construed as an official Department of the Army position unless so designated by other authorized documents. 


\title{
Estimating growing-season root zone soil moisture from vegetation index-based evapotranspiration fraction and soil properties in the Northwest Mountain region, USA
}

\begin{abstract}
A soil moisture retrieval method is proposed, in the absence of ground-based auxiliary measurements, by deriving the soil moisture content relationship from the satellite vegetation index-based evapotranspiration fraction and soil moisture physical properties of a soil type. A temperature-vegetation dryness index threshold value is also proposed to identify water bodies and underlying saturated areas. Verification of the retrieved growing season soil moisture was performed by comparative analysis of soil moisture obtained by observed conventional in situ point measurements at the 239-km ${ }^{2}$ Reynolds Creek Experimental Watershed, Idaho, USA (2006-2009), and at the US Climate Reference Network (USCRN) soil moisture measurement sites in Sundance, Wyoming (2012-2015), and Lewistown, Montana (2014-2015). The proposed method best represented the effective root zone soil moisture condition, at a depth between 50 and $100 \mathrm{~cm}$, with an overall average $R^{2}$ value of 0.72 and average root mean square error (RMSE) of 0.042 .
\end{abstract}

\section{Introduction}

Soil moisture modulates agriculture, hydrology and meteorology through its controls on surface fluxes of water and heat and through large-scale circulation. Therefore, soil moisture information is crucial in the simulation of floods and droughts, atmospheric circulation and global climate change (Berg et al. 2017). Information on root zone soil moisture, especially in the growing season, is significant from a global food security point of view (Kang et al. 2009). The growing season root zone soil moisture as a plant stress indicator plays a significant role in determining field-scale irrigation schedules, especially in the arid and semi-arid regions (Hill 2002).

Site measurements can provide relatively accurate estimates of soil moisture, but such techniques are limited due to the need for a variety of surface accessory measurements, which are difficult to obtain to cover a large area sufficiently. This difficulty usually leads to spatial and temporal extrapolation and interpolation of data with limited accuracy. Though remote sensing technology for soil moisture estimation is limited to surface soil moisture, the top few centimetres in a soil profile, it has several marked advantages over conventional "point" measurements: it can provide large and continuous spatial coverage within a short time and it is economical when the same spatial information is required. Research and development of an effective method for obtaining deeper soil profile, effective root zone, moisture content information from satellite imagery data is significant that aids in measuring water related stress in plants and environment. Realistic effective root zone soil moisture initial value is a primary driver for a physics-based hydrological model's effective simulation of surface water and groundwater interaction, through infiltration or exfiltration, and land atmospheric interaction, through evapotranspiration.

Soil moisture limits potential evapotranspiration to actual evapotranspiration (Anderson et al. 2007, Hain et al. 2009). Hence, soil moisture is directly linked to evaporative fraction (Ahmad and Bastiaanssen 2003, Fleming et al. 2005). The evaporative fraction represents the partitioning of radiant energy (Brutsaert and Sugita 1992, Crago 1996) in estimating energy available for evapotranspiration (latent heat flux) calculation. Although the energy balance residual method is a robust approach in calculating the evaporative fraction, the approach has its limitations (Gowda et al. 2007); these set back its employment, especially in ungauged basins around the globe. One such limitation is the reliance on groundbased auxiliary measurements. There are several regressionbased, simpler, remotely sensed multi-index soil moisture estimation methods (Carlson 2007, Zhang et al. 2008, Hosseini and Saradjian 2011, Sandholt et al. 2002), which do not take account of the energy balance residual. Although these methods are simple, they do not explicitly take account of soil, porous medium, physical properties such as field capacity and wilting point in the soil moisture estimation formulation. Each challenge encountered both in a complex and in a simplified soil moisture retrieval method behoves the scientific community to take an integrated approach in an effort to improve/optimize the accuracy, resolution and timeliness as well as ease-of-use of remotely sensed data for the information yield needed by professionals (Srivastava et al. 2014). 
The purpose of this study is to develop a simple, computationally straightforward, high-resolution growing season "root zone" soil moisture estimation relationship based on the vegetation indexderived evapotranspiration fraction, in the Northwest Mountain region of Idaho, Wyoming and Montana (USA), by taking into account the soil moisture physical properties, which bypasses the complexity and requirements of ground-based auxiliary measurements, especially in an ungauged similar environment.

\section{Study area and data}

\subsection{Green River}

The study area, shown in Figure 1, is located in the northern Green River Basin of New Fork watershed, Sublette County, western Wyoming (Chafin and Kimball 1992). This area is an arid to semi-arid region and is sparsely inhabited. The Green River Basin is the major drainage of the Colorado River Basin and the New Fork watershed is the northern headwater tributary of the Green River. The average annual precipitation in headwaters of the Green River is as high as $889 \mathrm{~mm}$. Welder (1968) reported that the average annual precipitation at Pinedale, a town located in this study area, was $269 \mathrm{~mm}$.

\subsection{Reynolds Creek Experimental Watershed}

The Reynolds Creek Experimental Watershed (RCEW), with a catchment area of $239 \mathrm{~km}^{2}$ (Fig. 2), is located in southwest Idaho and the inter-mountain region of the northwestern
USA (Slaughter et al. 2001). The elevation ranges from 750 to $2100 \mathrm{~m}$ a.s.l. Although snow is dominant at the highest elevations, rain is generally dominant in the watershed. Precipitation in the RCEW varies from $250 \mathrm{~mm} /$ year at lower elevations to more than $1100 \mathrm{~mm} /$ year at higher elevations. Land cover in the watershed is dominated by different subspecies of sagebrush, with heights in the range 0.30$0.60 \mathrm{~m}$ (Seyfried et al. 2000).

\subsection{USCRN soil moisture measurement sites in Montana and Wyoming}

The US Climate Reference Network (USCRN) soil moisture measurement sites (Bell et al. 2013) in Sundance, Wyoming $\left(44.52^{\circ} \mathrm{N}, 104.44^{\circ} \mathrm{W}\right)$, and Lewistown, Montana $\left(46.88^{\circ} \mathrm{N}\right.$, $110.29^{\circ} \mathrm{W}$ ), are also taken as study sites. The USCRN soil moisture measurement sites are included in the International Soil Moisture Network (Dorigo et al. 2013). Figure 3 shows the locations of the USCRN soil moisture sites used in this study.

\subsection{Data}

The US Geological Survey (USGS 2017) Earth Resources Observation and Science (EROS) Center Science Processing Architecture $(\mathrm{ESPA})^{1}$ on-demand interface provides $30-\mathrm{m}$ Landsat Surface Reflectance, with atmospheric corrections applied, Level-2 science products that include the spectral indices products for Landsat 4-5 Thematic Mapper (TM),

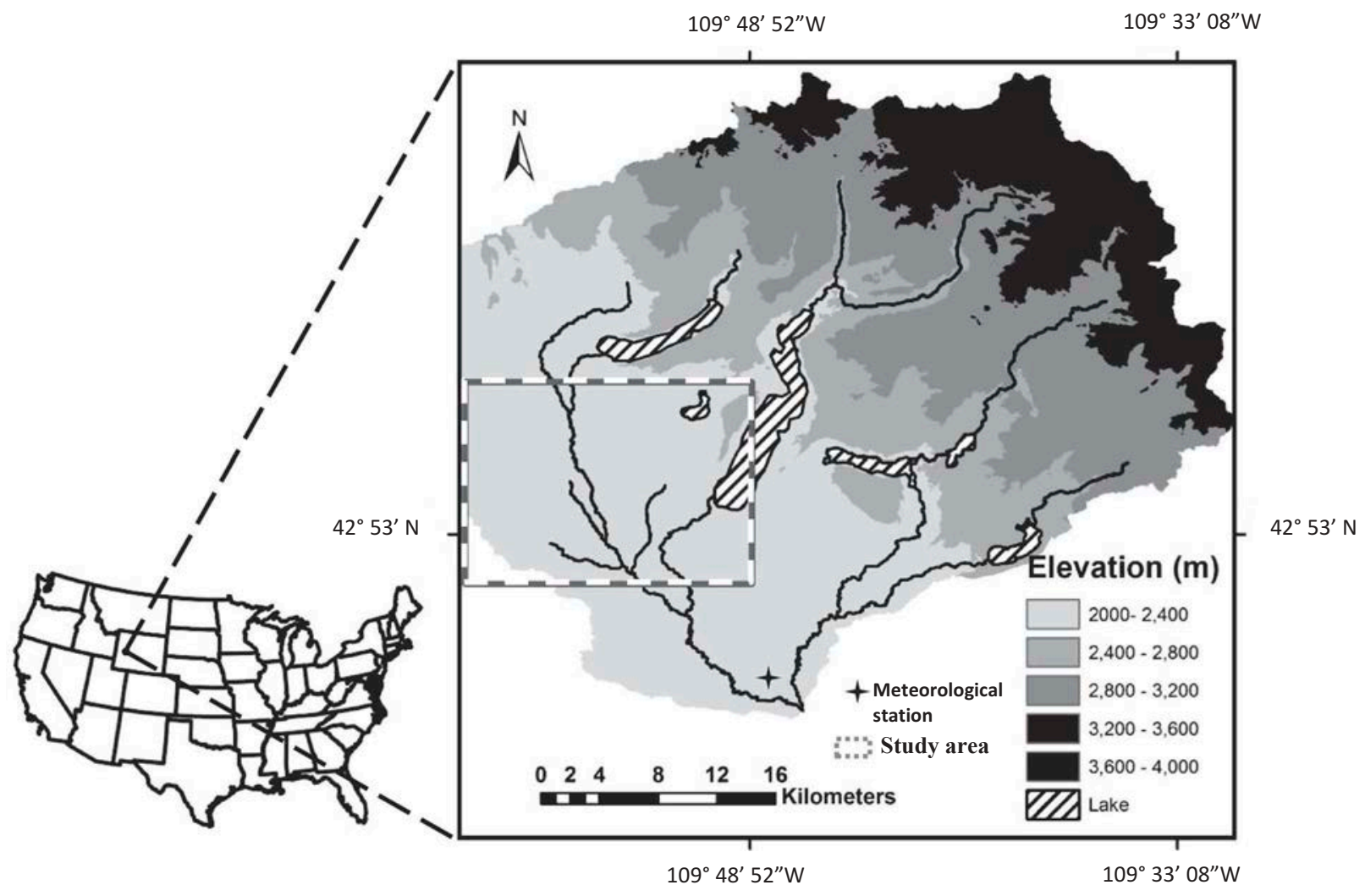

Figure 1. Map based on the 30-m DEM showing the topographic structure of the Green River Basin sub-watershed and its location in the USA. 


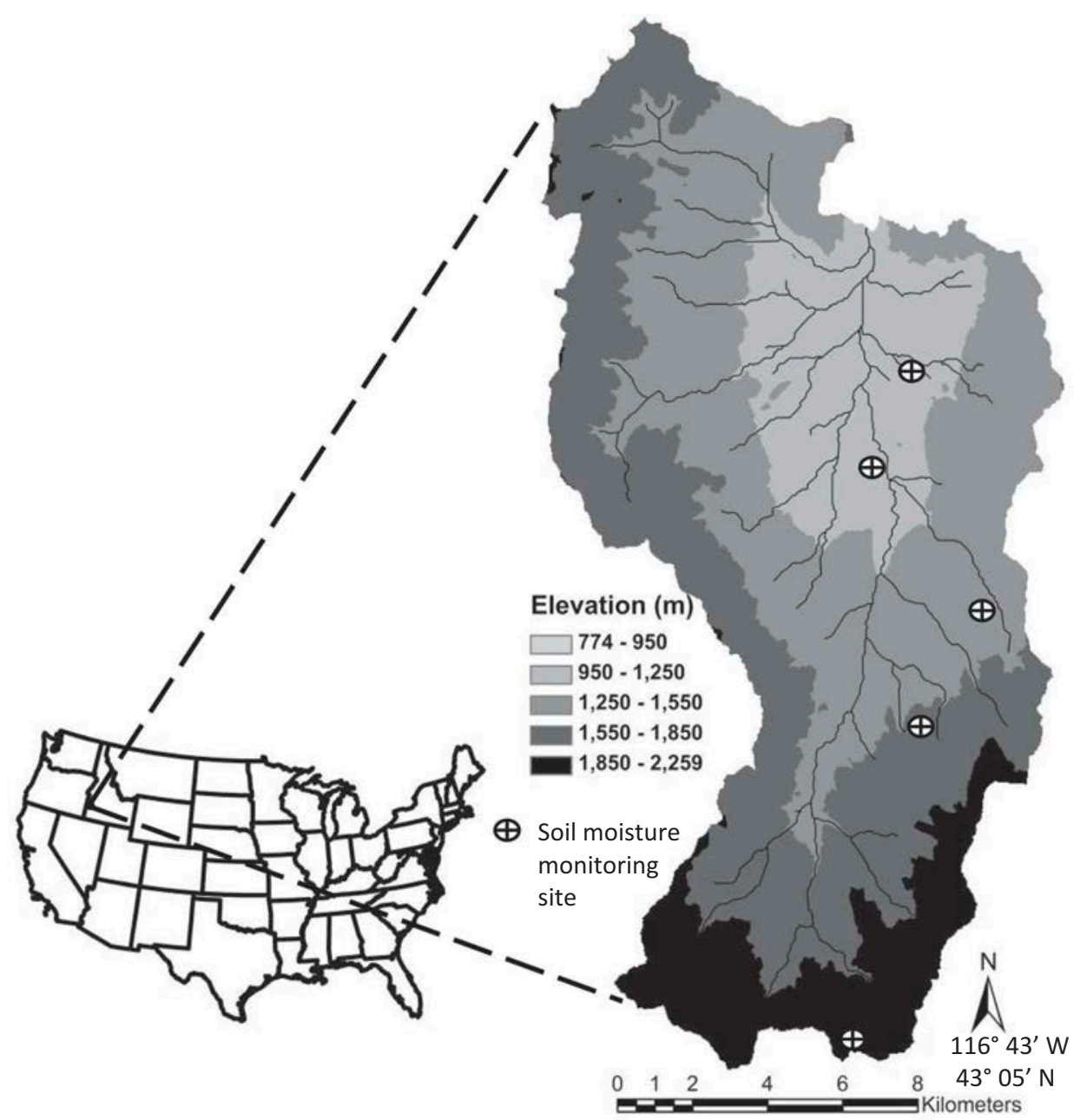

Figure 2. Map based on the 30-m DEM showing the topographic structure of the Reynolds Creek Experimental Watershed and its location in the USA.

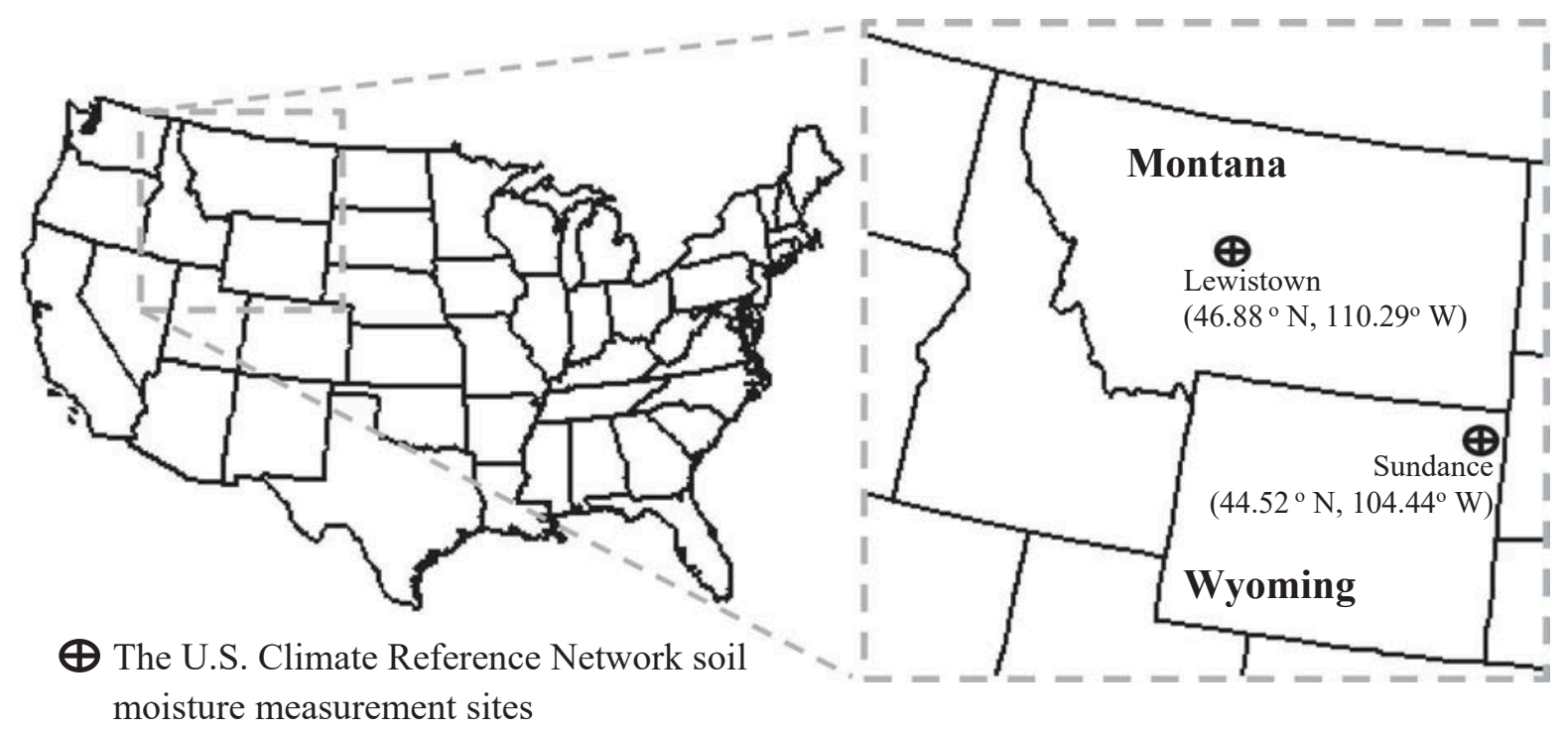

Figure 3. USCRN soil moisture measurement sites in Montana and Wyoming, USA. 
Landsat 7 Enhanced Thematic Mapper Plus (ETM+), and Landsat 8 Operational Land Imager (OLI)/Thermal Infrared Sensor (TIRS). The Normalized Difference Vegetation Index (NDVI), one of the on-demand spectral indices products, was used in all of the vegetation index analyses carried out in this study. The USGS Global Visualization Viewer ${ }^{2}$ was used to identify the clear-day images in the growing season. The wilting point $\left(\theta_{\mathrm{wp}}\right)$, field capacity $\left(\theta_{\mathrm{fc}}\right)$ and volumetric water content in the study area were derived from the Natural Resource Conservation Service (NRCS) SURRGO database ${ }^{3}$ using established pedotransfer functions that yield $\theta_{\mathrm{wp}}$ and $\theta_{\mathrm{fc}}$ as functions of soil texture (Rawls et al. 1982, 1983). The land-cover maps for the study area were derived from the National Land Cover Database (NLCD). ${ }^{4}$

The observed soil moisture data for the June-September growing seasons of 2006-2009, for the moisture measuring stations in the RCEW (Fig. 2), were obtained from the public database at Northwest Watershed Research Center, Reynolds Creek Experimental Watershed, Public-use Datafiles and Documentation (Seyfried et al. 2000).

The USCRN growing season (June-September) observed soil moisture data from 2012-2015 and 2014-2015 were used in this study for the soil moisture measurement sites at Sundance, Wyoming, and Lewistown, Montana, respectively. The observed soil moisture data for the moisture measuring USCRN stations were obtained from the USCRN Public-use Data files and Documentation ${ }^{5}$ (Bell et al. 2013).

\section{Methodology}

\subsection{Evapotranspiration fraction and soil water content relationship derivation}

Actual evapotranspiration (AET) can be defined as a largely empirical function of plant-specific potential evapotranspiration (PET) and soil moisture content (SM), or a soil moisture matric potential and threshold value above which actual and potential evapotranspiration are equal. Calculation of the AET is obtained by a reduction relationship, using functions that describe the influence of the available moisture (Bagrov 1953, Budyko and Zubenok 1961, Baier and Robertson 1966, Norero 1969, Minhas et al. 1974, Renger et al. 1974, Eagleson 1978, Glugla 1980), as:

$$
\frac{\mathrm{AET}}{\mathrm{PET}}=f(\mathrm{SM})
$$

Budyko and Zubenok (1961) define the soil moisture function in Equation (1) as:

$$
\frac{\mathrm{AET}}{\mathrm{PET}}=\frac{\mathrm{SM}}{\mathrm{PAM}}
$$

where SM is the actual available soil moisture and PAM is plant-available soil moisture at field capacity. In Equation (2), $\mathrm{SM} / \mathrm{PAM}$ can be taken as the soil wetness index, defined as:

$$
\frac{\mathrm{SM}}{\mathrm{PAM}}=\frac{\left(\theta-\theta_{\mathrm{wp}}\right)}{\left(\theta_{\mathrm{fc}}-\theta_{\mathrm{wp}}\right)}
$$

where $\theta$ is the actual soil moisture content; and $\theta_{\mathrm{fc}}$ and $\theta_{\mathrm{wp}}$ are the field capacity moisture content and wilting point moisture content, respectively, for the soil type at the location.

From Equations (2) and (3), it follows that:

$$
\frac{\mathrm{AET}}{\mathrm{PET}}=\frac{\left(\theta-\theta_{\mathrm{wp}}\right)}{\left(\theta_{\mathrm{fc}}-\theta_{\mathrm{wp}}\right)}
$$

where AET/PET is the crop coefficient, $K_{c}$ (Dyck 1983). Trezza (2002), Tasumi (2003) and Allen et al. (2007c) showed that the reference evapotranspiration fraction $\left(\mathrm{ET}_{\mathrm{rf}}\right)$ is similar to $K_{c}$ (Allen et al. 1998):

$$
\mathrm{ET}_{\mathrm{rf}}=\frac{\mathrm{AET}}{\mathrm{ET}_{r}}
$$

where $\mathrm{ET}_{r}$ is the reference evapotranspiration, calculated using the FAO Penman-Monteith method and data originating from a weather station. The parameter $\mathrm{ET}_{\mathrm{rf}}$ accounts for water stress and other evapotranspiration (ET)-reducing environmental stresses (Allen et al. 2005). Considering $\mathrm{ET}_{\mathrm{rf}}$ to be equal to $K_{c}$ (Trezza 2002, Allen et al. 2007c) and related to the soil moisture function defined in Equation (4), one obtains:

$$
\mathrm{ET}_{\mathrm{rf}}=\frac{\left(\theta-\theta_{\mathrm{wp}}\right)}{\left(\theta_{\mathrm{fc}}-\theta_{\mathrm{wp}}\right)}
$$

From Equation (6), spatially distributed soil moisture content, $\theta_{i}$, at any spatial location, $i$, is derived as:

$$
\theta_{i}=\mathrm{ET}_{\mathrm{rf} i}\left(\theta_{\mathrm{fc} i}-\theta_{\mathrm{wp} i}\right)+\theta_{\mathrm{wp} i}
$$

This study used the theoretical basis, mentioned above in this section, to derive a relationship between soil moisture, ET fraction and soil properties, as defined by Equation (7), for the development of a spatially-distributed soil moisture estimation tool. Although the energy balance residual method estimates AET with underlying complexity in the solution of sensible heat flux (Tasumi 2003), the calculation of $\mathrm{ET}_{\mathrm{rf}}$ and AET still need ground-based auxiliary measurements of meteorological data (Allen et al. 2007c). As ground-based meteorological stations are sparse, Equation (7) is not yet readily applicable. Therefore, this research looked into the possible inversion of $\mathrm{ET}_{\mathrm{rf}}$ through the globally available $30-\mathrm{m}$ resolution NDVI of Landsat Surface Reflectance Level-2 Science Products. ${ }^{6}$

\subsection{Evapotranspiration fraction inversion through NDVI}

Similarities between the crop coefficient curve and a satellitederived vegetation index show potential for modelling a crop coefficient as a function of the vegetation index (Kamble et al. 2013, Mutiibwa and Irmak 2013). The possibility of directly estimating the crop coefficient from the vegetation index based on spectral-band intensities was further investigated in this study.

\footnotetext{
${ }^{2}$ http://glovis.usgs.gov/.

${ }^{3} \mathrm{http}: / /$ websoilsurvey.sc.egov.usda.gov/App/WebSoilSurvey.aspx.

${ }^{4}$ http://www.mrlc.gov/.

${ }^{5}$ https://www1.ncdc.noaa.gov/pub/data/uscrn/products/daily01/.

${ }^{6}$ https://landsat.usgs.gov/landsat-surface-reflectance-data-products.
} 
The differential reflection of green vegetation in the visible and near-infrared portions of the spectrum provides a method to remotely monitor vegetation, defined as (Nicholson and Farrar 1994):

$$
\mathrm{NDVI}=\frac{C h \_2-C h \_1}{C h \_2+C h \_1}
$$

where Ch_1 and Ch_2 are the reflectance in the visible (red) spectral band $(0.55-0.68 \mu \mathrm{m})$ and near-infrared (NIR) spectral band $(0.73-1.1 \mu \mathrm{m})$, respectively. The NDVI value depends on electromagnetic energy absorption in the red spectral band, signifying the density of leaf chlorophyll, and the reflectance of NIR electromagnetic energy, signifying the density of green leaves (Tucker and Sellers 1986). As NDVI is a measure of absorption of photosynthetically active electromagnetic radiation, it is a physiological representation of the photosynthetic capacity of the canopy (Sellers 1985).

The spatial distribution of $\mathrm{ET}_{\mathrm{rf}}$, and data used in the development of the relationship with NDVI were obtained from the surface energy balance residual algorithm in the Mapping EvapoTranspiration at high Resolution with Internalized Calibration model (METRIC; Allen et al. 2007a, 2007b, 2007c) applied in the study area (Pradhan et al. 2012).

\subsubsection{Surface energy balance $E T_{\text {rf }}$}

Actual evapotranspiration (AET) depends on the root zone soil moisture: when it is decreased, AET is reduced due to hydraulic resistance of the soil, and when it is wet, sensible heat flux is almost zero, resulting in more radiation energy available for latent heat flux and thereby increased AET. Hence, AET represents the available root zone soil moisture. As the Surface Energy Balance Algorithm for Land (SEBAL; Bastiaanssen et al. 1998) and METRIC (Allen et al. 2007c) models explicitly take account of these physical processes in the calculation of AET, based on the partitioning of radiant energy via evaporative fraction, these models have been deployed successfully in the past for the extraction of root zone soil moisture (Ahmad and Bastiaanssen 2003, Pradhan et al. 2012, Hong et al. 2016). This is one of the reasons for employing the $\mathrm{ET}_{\mathrm{rf}}$ calculated by the METRIC model (Allen et al. 2007c) for the development of the relationship of the evapotranspiration fraction with NDVI, for use in the root zone soil moisture estimation formulation defined by Equation (7). Moreover, the METRIC model algorithm developed in the applications manual by Allen et al. (2007c) was from the Idaho implementation, which is in the Northwest Mountain region, the region of this study.

In the surface energy balance residual algorithm of the METRIC model, an instantaneous value of AET is defined as the ratio of latent heat flux, $\mathrm{LE}\left(\mathrm{W} \mathrm{m}^{-2}\right)$, to the latent heat of vaporization $(\lambda)$ :

$$
\mathrm{AET}=3600 \frac{\mathrm{LE}}{\rho_{w} \lambda}
$$

where 3600 is the time conversion from seconds to hours, and $\rho_{w}$ is the water density $\left(\sim 1.0 \mathrm{Mg} \mathrm{m}^{-3}\right)$. The LE is defined as the residual of the surface energy balance:

$$
\mathrm{LE}=R_{n}-G-H
$$

where $R_{n}$ is net radiation, $G$ is the soil heat flux and $H$ is the sensible heat flux (all in $\mathrm{W} \mathrm{m}^{-2}$ ), calculated following the METRIC model algorithm (Allen et al. 2007c). The reference manual for METRIC (Allen et al. 2007c) provides the details for computing the spectral radiance of each band in the Landsat 5 TM (thematic mapper) from the pixel digital numbers of each band, and for calculating at-surface reflectance with atmospheric correction. This band-based at-surface reflectance, along with a digital elevation model (DEM) and meteorological data, such as air temperature and wind velocity, are used to compute surface temperature, $R_{n}, G$ and $H$. Clear-sky Landsat 5 TM of 11 September 2009 was used to compute the energy fluxes defined in Equation (10).

In the ET algorithm of METRIC, $\mathrm{ET}_{\mathrm{rf}}$ (Equation (5)) is defined as the ratio of instantaneous AET for each pixel to the alfalfa-reference ET calculated using the standardized ASCE Penman-Monteith equation for alfalfa, following the procedures given in ASCE-EWRI (2005). The PET is considered equal to the reference ET for a tall crop calculated from the meteorological data measured at a ground-based station (Allen 2001, ASCEEWRI 2005). This alfalfa-reference ET was calculated by employing ground-based meteorological data from Ralph Wenz Field airport at Pinedale, Wyoming (see Fig. 1), and deploying the standardized ASCE Penman-Monteith equation in REF-ET software (Allen 2001). The AET was calculated by Equation (9). Figure 4 shows the METRIC model $\mathrm{ET}_{\mathrm{rf}}$ distribution at the Green River study area (see Fig. 1).

\subsection{2 $E T_{\text {rf }}$ and NDVI deterministic relationship and uncertainty analysis}

Two hundred scatter plots of $\mathrm{ET}_{\mathrm{rf}}$ versus NDVI were obtained from within the study area (Fig. 1). Each scatter plot represents an $\mathrm{ET}_{\mathrm{rr}}-\mathrm{NDVI}$ pair of all 461 rows of a column in the study area. The 200 such scatter plots of $\mathrm{ET}_{\mathrm{rf}}$ and NDVI samples from 200 columns were used for the parameter value uncertainty analysis of the deterministic relationship development of $\mathrm{ET}_{\mathrm{rf}}$ and NDVI. A best-fit regression relationship was developed for each scatter plot; in each case, a linear relationship represented the best-fit regression. Figure 5 shows the distribution of the best-fit regression coefficient of determination $\left(R^{2}\right)$ values ranging from 0.55 to 0.8 , with a mean of 0.72 . This mean $R^{2}$ value indicates that $\mathrm{ET}_{\mathrm{rf}}$ is spatially highly correlated to NDVI, which hints at the development of a generalized linear relationship between $\mathrm{ET}_{\mathrm{rf}}$ and NDVI in the study area; however, a variation in $R^{2}$ for samples from different locations also indicates that this correlation is sensitive to the spatial distribution of NDVI values. Therefore, a probability density function, as shown in Figure 6, was used to obtain the likelihood deterministic value of the slope and intercept from spatially-distributed samples.

Figure 6(a) shows the distribution of the slope of the $\mathrm{ET}_{\mathrm{rf}}$ and NDVI linear deterministic relationship, with a slope ranging from 1 to 1.7 (mean: 1.33); it also shows that the slope values are highly concentrated around this mean value. The $95 \%$ confidence interval of the slope value from the central limit theorem was 1.355 (upper limit) to 1.316 (lower limit). The predicted $\mathrm{ET}_{\mathrm{rf}}$ was not sensitive to this narrow uncertainty margin of the deviation of the NDVI slope. Therefore a mean slope of 1.33 was generalized for the study region. 


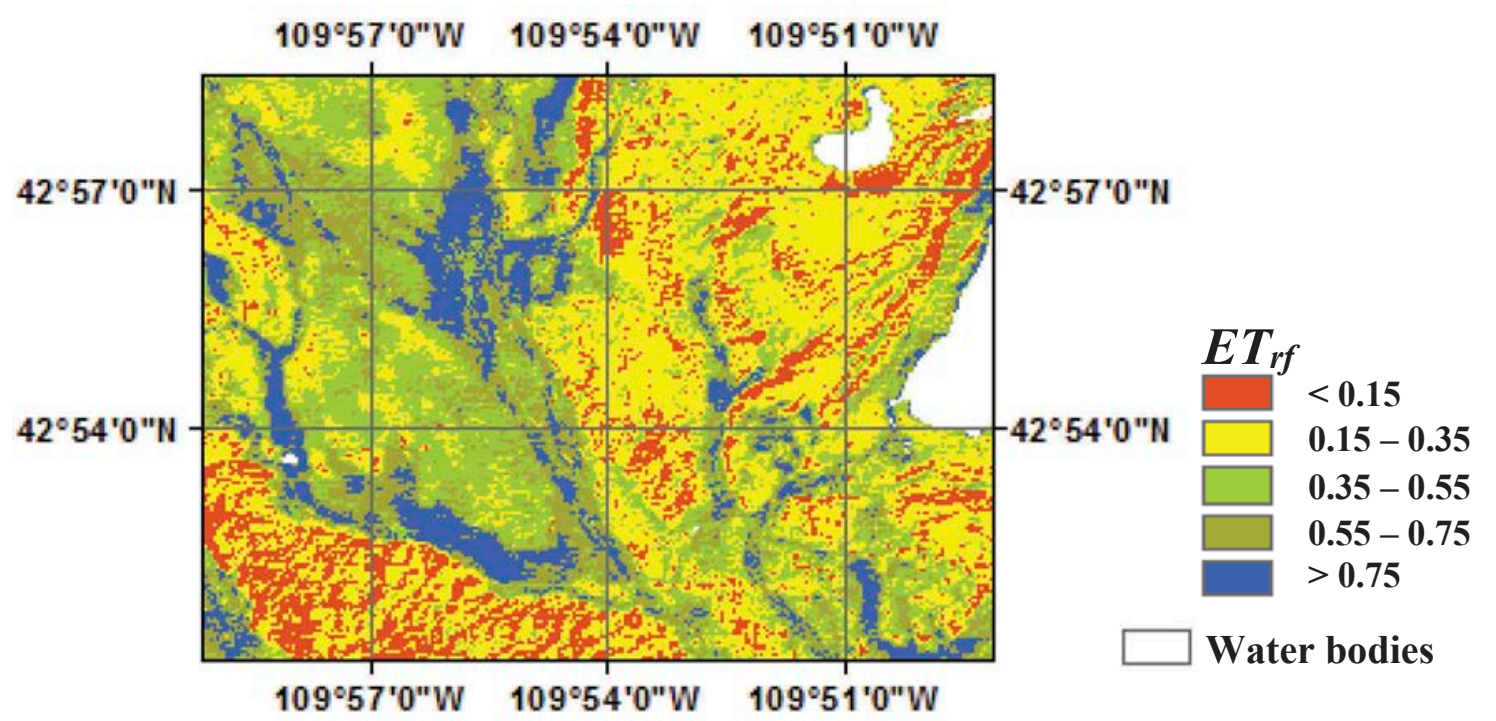

Figure 4. $E T_{\text {rf }}$ distribution at Green River study area on 11 September 2009.

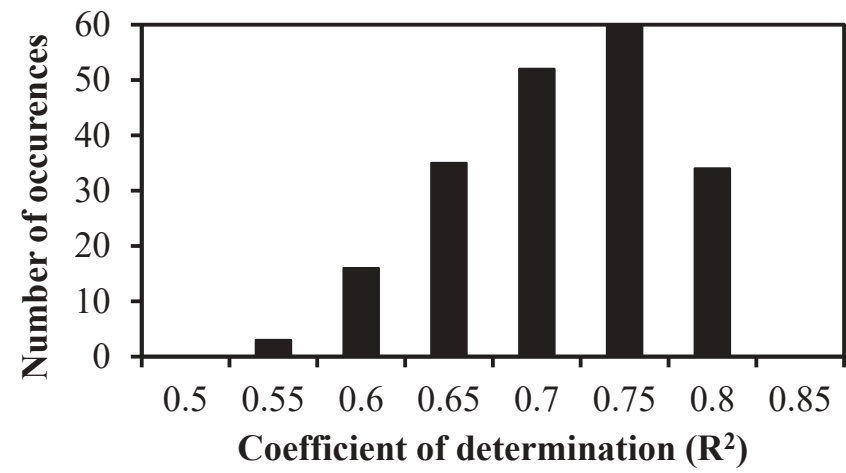

Figure 5. Spatial distribution of the regressed NDVI and $\mathrm{ET}_{\text {rf }} R^{2}$ values.

Similarly, Figure 6(b) shows the distribution of the intercept of the $\mathrm{ET}_{\mathrm{rf}}$ and NDVI linear deterministic relationship, ranging from -0.16 to 0.04 (mean: -0.049 ); it also shows that the intercept values are highly concentrated around this mean value. The $95 \%$ confidence interval of the slope value was -0.043 (upper limit) to -0.054 (lower limit). The predicted $\mathrm{ET}_{\mathrm{rf}}$ was not sensitive to this narrow uncertainty margin of the deviation of the NDVI intercept. Therefore, a mean intercept of -0.049 was generalized for the study region.

From this parametric uncertainty analysis of the linear deterministic relationships between $\mathrm{ET}_{\mathrm{rf}}$ and NDVI, the likelihood function was developed as:

$$
\mathrm{ET}_{\mathrm{rf}}=1.33 \mathrm{NDVI}-0.049
$$

Figure 7 shows the scatter plots of the surface energy balance residual algorithm-based $\mathrm{ET}_{\mathrm{rf}}$, defined by Equation (5), against NDVI-based $\mathrm{ET}_{\mathrm{rf}}$, defined by Equation (11). Each scatter plot in Figure 7 represents 461 pairs of data in rows of a column, starting at the far left of the study area, with subsequent columns at intervals of $30 \mathrm{~m}$. The data samples used in the verification analysis of Figure 7 were not included in deriving Equation (11). The $R^{2}$ values and RMSE are shown in Figure 7 for each scatter plot.
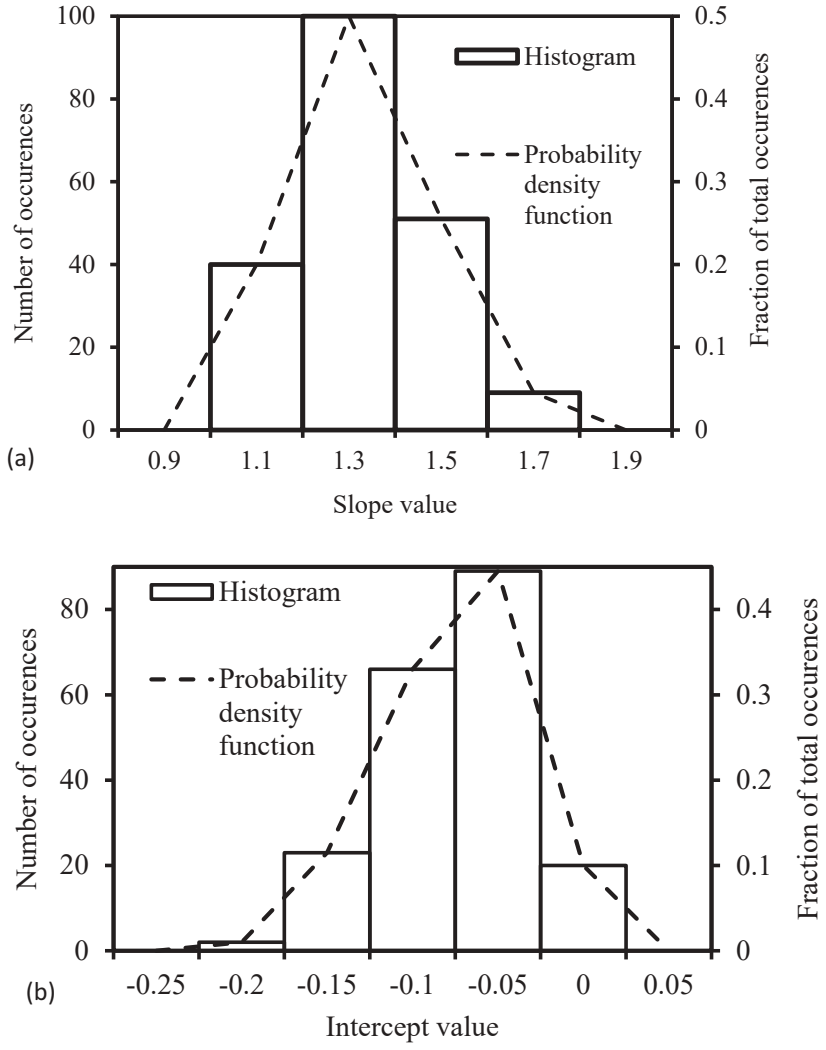

Figure 6. Identification of (a) the slope value and (b) the intercept value from spatial distribution of the regressed NDVI and $\mathrm{ET}_{\text {rf }}$ slope values.

\subsection{Root zone soil moisture estimation method}

From Equations (7) and (11), the spatially-distributed soil moisture content, $\theta_{i}$, at any spatial location $i$ is derived as:

$$
\theta_{i}=\left(1.33 \mathrm{NDVI}_{i}-0.049\right)\left(\theta_{\mathrm{fci}}-\theta_{\mathrm{wp} i}\right)+\theta_{\mathrm{wp} i}
$$

This study developed and deployed Equation (12) as the root zone soil moisture estimation model, hereafter referred to as SERVES (Soil moisture Estimation of Root 

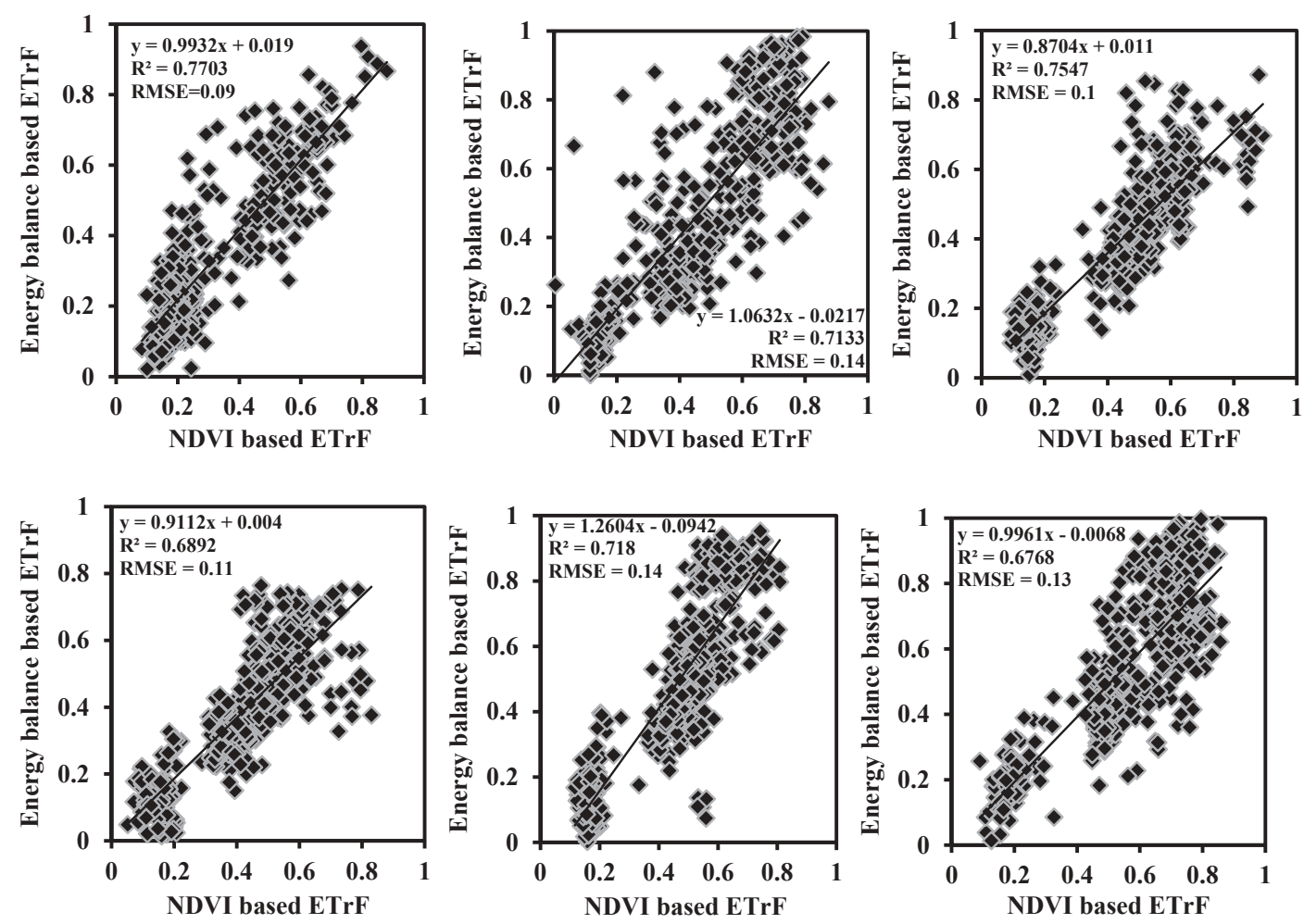

Figure 7. Comparison of the NDVI-based evaporative fraction and the surface energy balance-based evaporative fraction. Each scatter plot represents 461 pairs of surface energy balance-based $\mathrm{ET}_{\text {rf }}$ and NDVI-based $\mathrm{ET}_{\mathrm{rf}}$ in rows of a column, starting at the far left of the Green River study area in Figure 1 with subsequent columns at intervals of $30 \mathrm{~m}$

zone through Vegetation index-based Evapotranspiration fraction and Soil properties).

\subsection{Identification of water bodies}

The NDVI does occasionally assume negative values, especially for water bodies such as wetlands, rivers and lakes. Water, clouds and snow have larger reflectance at the red than at the NIR wavelengths, so these features present negative index values. Therefore, to distinguish the saturated and wet areas covered by water bodies, wetlands, rivers and lakes, an analysis was made in the thermal infrared (TIR) band, as soil water content is a crucial variable in TIR research. The temperature vegetation dryness index (TVDI; Sandholt et al. 2002) employs the TIR bands. Usually a triangular or a trapezoidal shape appears in the scatter plot space of land surface temperature $\left(T_{\mathrm{s}}\right)$ versus NDVI (Sandholt et al. 2002, Xin et al. 2006), where the upper sloping edge is the dry edge with lower soil moisture, and the lower sloping edge is the wet edge with higher soil moisture and evapotranspiration capacity (Holzman et al. 2014). A $T_{s}$ value on the dry edge is the maximum value $\left(T_{s}\right.$, $\max$ ) among all the $T_{\mathrm{s}}$ values that fall under the same NDVI in the scatter plot. Likewise, a $T_{\mathrm{s}}$ value on the wet edge is the minimum value $\left(T_{\mathrm{s}, \mathrm{min}}\right)$ among all the $T_{\mathrm{s}}$ values that falls under the same NDVI in the scatter plot. Usually, $T_{s, \min }$ is independent of NDVI under saturation conditions.

Figure 8(a) shows the scatter plot of $T_{\mathrm{s}}$ versus NDVI in the Green River study area. The upper sloping dry edge of $T_{\mathrm{s}, \max }$ in Figure 8(a) is a linear function of NDVI, with a slope of 22 and an intercept of 317, and the lower wet edge of $T_{\mathrm{s}, \min }$ in
Figure $8(\mathrm{a})$ is independent of NDVI and has a constant value of $287 \mathrm{~K}$.

The TVDI is defined as:

$$
\text { TVDI }=\frac{T_{\mathrm{s}}-T_{\mathrm{s}, \min }}{T_{\mathrm{s}, \max }-T_{\mathrm{s}, \min }}
$$

In the Green River study area, the water overlaying saturated areas was found to occur under lower $T_{\mathrm{s}}$ values and the difference between $T_{\mathrm{s}, \max }$ and $T_{\mathrm{s}, \min }$ for those areas was comparatively larger than rest of the land-cover types; this makes TVDI calculated by Equation (13) have a lower value. The Green River study area includes lakes, and this lower TVDI value is shown by the Soda Lake and Fermont Lake, as shown in Figure 8(b). This study identified a critical threshold value of 0.2 in the TVDI map, below which are wet locations, mostly water bodies, and underlying saturated areas. In Figure $8(\mathrm{~b})$, water bodies identified by the TVDI threshold of 0.2 are compared with that defined by the National Land Cover Database (NLCD). In Soda Lake and Fermont Lake, the accuracy, defined as the ratio of TVDI threshold-defined lake boundary to NLCD-defined lake boundary, was 1.15 and 1.17, respectively. From the accuracy calculation, the TVDI threshold of 0.2 overestimated the lake area as compared to the NLCD. Water bodies such as lakes keep the surrounding land saturated, and this surrounding saturated area is not included in the lake boundary defined by NLCD (Homer et al. 2015), whereas the TVDI threshold method defined herein included the land area with low surface temperature and low NDVI as saturated extent, thereby overestimating the lake area compared to that identified from the NLCD. From the 


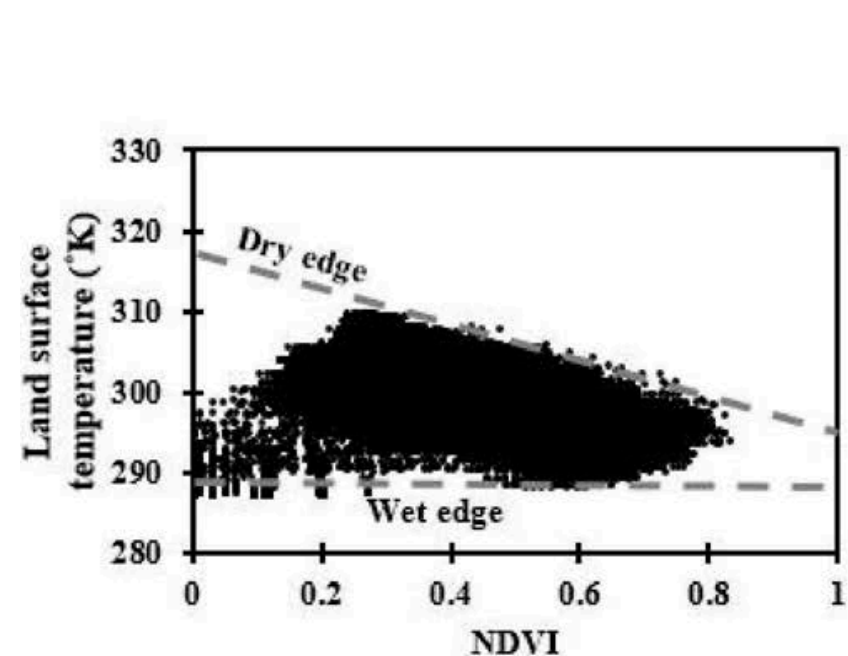

(a)

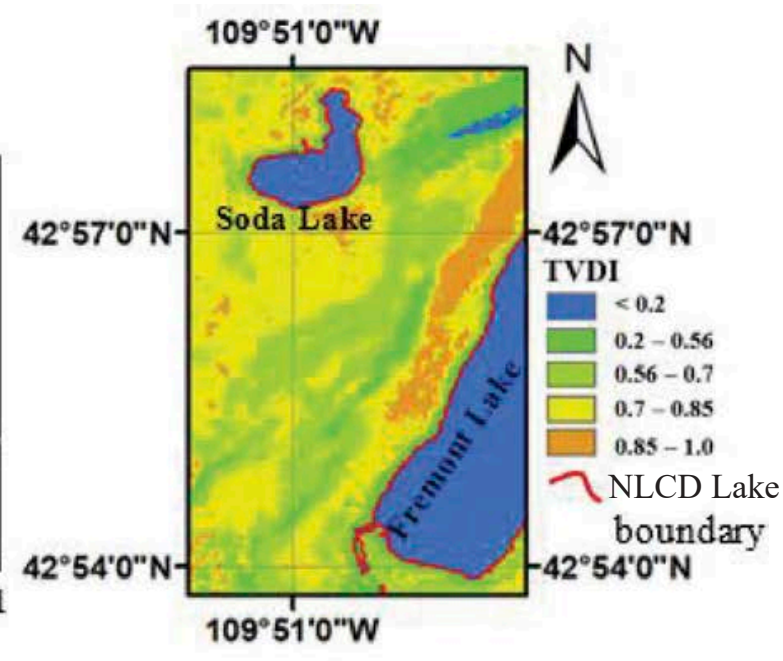

(b)

Figure 8. TVDI analysis: (a) maximum and minimum land surface temperature identification from scatter plot of land surface temperature and NDVI in the Green River study area; (b) comparison of water bodies identified by the TVDI threshold method with those defined by the National Land Cover Database.

overall analysis, a location having TVDI $<0.2$ is used to identify soil moisture at field capacity level, defined as:

$$
\theta_{i}=\theta_{\mathrm{fc} i} \text { if } \mathrm{TVDI}_{i}<0.2
$$

There are also various water extraction indices based on the fact that water bodies have large observance in the NIR band (Feyisa et al. 2014, Zhai et al. 2015). The TVDI has the advantage of being useful for identifying the possible extended saturated area around a water body. A comparative analysis of water extraction methods based on the NIR and TIR bands, including the water extraction method presented in this study, is a subject for future research.

\section{Results and discussion}

The Reynolds Creek Experimental Watershed in Idaho, the USCRN soil moisture measurement sites in Wyoming at Sundance and in Montana at Lewistown, and the Green River study area in Wyoming lie in similar climatic and physiographic regions of the continental United States, the Northwest mountain region. The SERVES equation (Equation (12)) was used to estimate the growing season soil moisture and compare it with site observations from the RCEW in Idaho and the USCRN measurement sites in Wyoming and Montana.

\subsection{Validation of the estimated soil moisture in the RCEW}

The SERVES model (Equation (12)) was used to estimate the soil moisture in the RCEW. The physical parameter values of soil that were identified in the watershed are listed in Table 1 and the corresponding soil types are shown in Figure 9(a). The $\theta_{\mathrm{wp}}$ and $\theta_{\mathrm{fc}}$ for the RCEW (Table 1) were derived from the NRCS SURRGO database using established pedotransfer functions as a function of soil texture (Rawls et al. 1982,
Table 1. Reynolds Creek Experimental Watershed soil moisture parameter estimates.

\begin{tabular}{lcc}
\hline Soil type & Field capacity & Wilting point \\
\hline Silt Loam & 0.33 & 0.13 \\
Sandy Loam & 0.29 & 0.06 \\
Sandy Clay Loam & 0.26 & 0.14 \\
Loamy Sand & 0.15 & 0.06 \\
Loam & 0.3 & 0.11 \\
Clay Loam & 0.35 & 0.1 \\
\hline
\end{tabular}

1983). Figure 9(b) shows the spatial distribution of estimated soil moisture in the watershed.

A comparative analysis of the estimated soil moisture was performed in the entire growing season (June-September) for the years 2006-2009. The observed soil moisture data for the corresponding moisture measuring stations were obtained from the NWRC, the RCEW and Public-use Data files and Documentation (Seyfried et al. 2011). The NDVI, obtained as described in Section 2.4, was used in all of the comparison verification analysis of the RCEW. In selecting the growingseason NDVI image, the following points were considered:

(a) high-quality Landsat images; and

(b) date of soil moisture observation close to the satellite overpass date.

Tables A1-A8 are presented in the Appendix to list the values of observed soil moisture available for each moisture measuring site, the NDVI values for the site in that period, the estimated values of $\mathrm{ET}_{\mathrm{rf}}$ (Equation (11)) and soil moisture (Equation (12)) for the dates considered. Likewise, Figures A1-A8 show the corresponding scatter plots of the observed versus calculated soil moisture given in Tables A1A8, respectively.

Table 2 shows the $R^{2}$ and RMSE values of estimated/predicted soil moisture compared with the observed values at depths of 15, 30, 60 and $90 \mathrm{~cm}$ (see Appendix, Figs A1-A8). It may be seen from Table 2 that the soil moisture estimation 


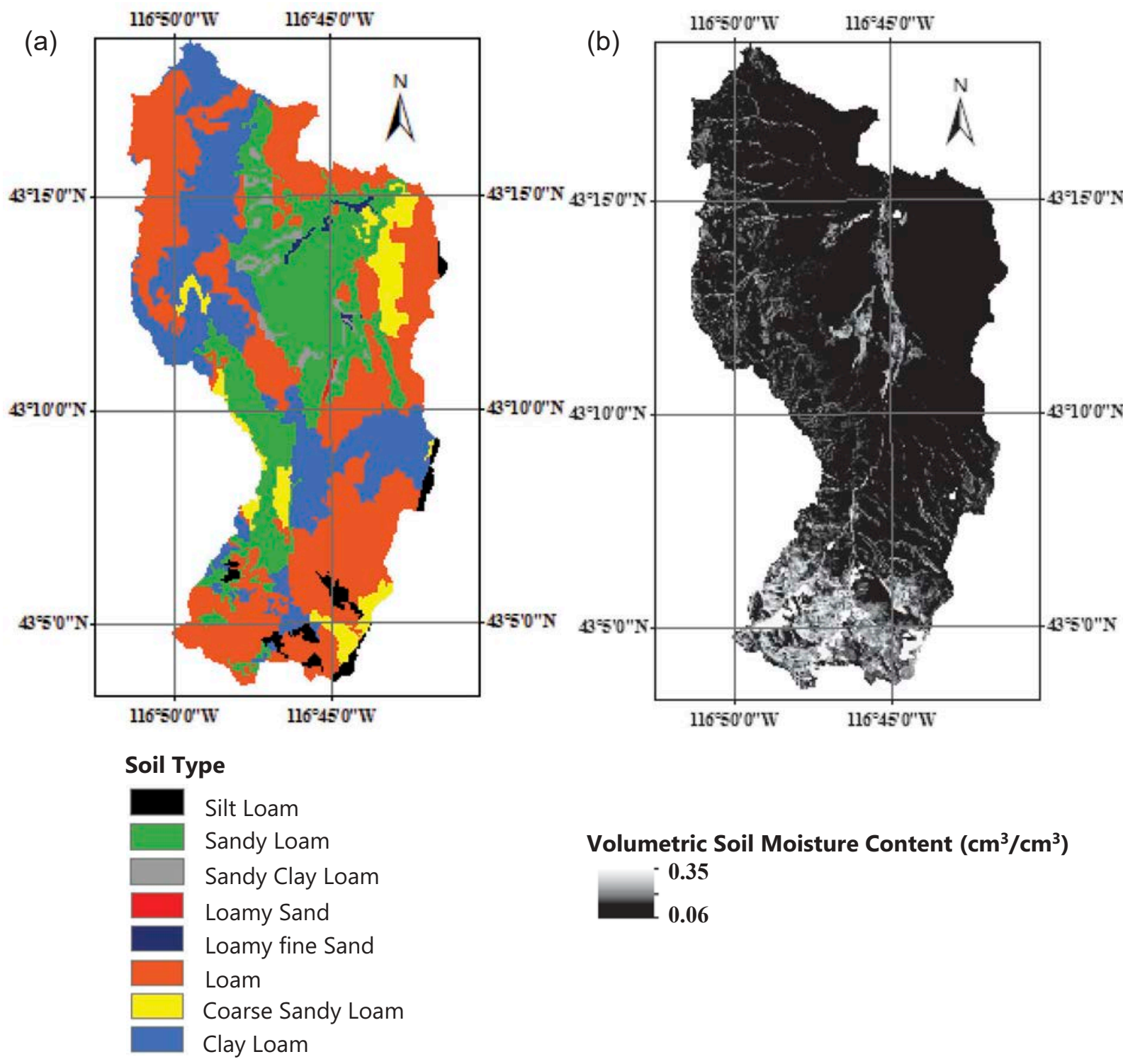

Figure 9. Reynolds Creek Experimental Watershed maps of (a) soil types identified from the SURRGO dataset and (b) estimated soil moisture for 11 September 2008.

method presented in this study performed best at a depth of between 60 and $90 \mathrm{~cm}$, with average $R^{2}$ of $0.040,0.12,0.55$ and 0.58, and average RMSE of 0.07, 0.07, 0.07 and 0.05 at depths of 15, 30, 60 and $90 \mathrm{~cm}$, respectively.

\subsection{Validation of the estimated soil moisture at Sundance, Wyoming}

The SERVES equation (Equation (12)) was used to estimate the soil moisture at the USCRN soil moisture measurement site in Sundance, Wyoming. A comparative analysis of the estimated soil moisture was performed for the entire growing season (June-September) for the years 2012-2015. The observed soil moisture and NDVI data were obtained as described in Section 2.4. Again, the selection of NDVI images took account of the following points:

(a) high-quality Landsat images; and (b) soil moisture observation date matches the satellite overpass date.

The soil type - sandy loam - was identified from the NRCS SURRGO database. The $\theta_{\mathrm{wp}}$ and $\theta_{\mathrm{fc}}$ were taken as 0.06 and 0.29 , as defined in Table 1 .

Table 3 presents the values of observed soil moisture at depths of 5,20,50 and $100 \mathrm{~cm}$, and the estimated soil moisture for the observed dates that match the satellite overpass dates, and Figure 10 shows the corresponding scatter plot of the observed versus calculated soil moisture. For Figure $10(\mathrm{a})-(\mathrm{d})$, the $R^{2}$ values were $0.40,0.13,0.258$ and 0.83 , and the RMSE were $0.155,0.096,0.039$ and 0.137 , respectively.

Similar to the RCEW soil moisture measurement sites, the Sundance moisture measurement site also showed that the best moisture prediction was in the depth range of 50$100 \mathrm{~cm}$, with the highest $R^{2}$ value of 0.838 at $100 \mathrm{~cm}$ depth, and the lowest RMSE of 0.039 at $50 \mathrm{~cm}$ depth. 
Table 2. Performance analysis of the estimated/predicted soil moisture at different depths in Reynolds Creek Experimental Watershed. Dates in the form mm/dd/ yyyy.

\begin{tabular}{|c|c|c|c|c|c|c|c|c|}
\hline \multirow[t]{2}{*}{ Observation date } & \multicolumn{4}{|c|}{$R^{2}$} & \multicolumn{4}{|c|}{ RMSE } \\
\hline & $15 \mathrm{~cm}$ & $30 \mathrm{~cm}$ & $60 \mathrm{~cm}$ & $90 \mathrm{~cm}$ & $15 \mathrm{~cm}$ & $30 \mathrm{~cm}$ & $60 \mathrm{~cm}$ & $90 \mathrm{~cm}$ \\
\hline $06 / 22 / 2006$ & 0.1323 & 0.0988 & 0.3375 & 0.471 & 0.095 & 0.092 & 0.09 & 0.01 \\
\hline $07 / 11 / 2007$ & 0.01 & 0.0273 & 0.4823 & 0.5467 & 0.081 & 0.05 & 0.0 .06 & 0.05 \\
\hline $08 / 27 / 2007$ & 0.0796 & 0.0041 & 0.5548 & 0.4732 & 0.067 & 0.07 & 0.072 & 0.067 \\
\hline $06 / 18 / 2008$ & 0.0519 & 0.0282 & 0.6761 & 0.6912 & 0.078 & 0.076 & 0.071 & 0.067 \\
\hline $07 / 30 / 2008$ & 0.0032 & 0.0388 & 0.5705 & 0.5732 & 0.072 & 0.063 & 0.063 & 0.057 \\
\hline $08 / 13 / 2008$ & 0.0131 & 0.0573 & 0.4733 & 0.5702 & 0.075 & 0.061 & 0.065 & 0.062 \\
\hline $09 / 10 / 2008$ & 0.0092 & 0.0831 & 0.5419 & 0.6338 & 0.05 & 0.062 & 0.06 & 0.063 \\
\hline $06 / 25 / 2009$ & 0.0275 & 0.6318 & 0.7237 & 0.6645 & 0.06 & 0.079 & 0.071 & 0.073 \\
\hline
\end{tabular}

Table 3. Observed and estimated soil moisture content at various depths from the USCRN soil moisture measurement site in Sundance, Wyoming, and Lewistown, Montana. Dates in the form $\mathrm{mm} / \mathrm{dd} / \mathrm{yyyy}$.

\begin{tabular}{|c|c|c|c|c|c|c|c|}
\hline \multirow[t]{2}{*}{ Observation date } & \multicolumn{4}{|c|}{ Observed moisture content $\left(\mathrm{cm}^{3} \mathrm{~cm}^{-3}\right)$} & \multirow[t]{2}{*}{ NDVI } & \multirow{2}{*}{$\begin{array}{l}\text { Estimated } \\
\qquad \mathrm{ET}_{\mathrm{rf}}\end{array}$} & \multirow{2}{*}{$\begin{array}{l}\text { Estimated moisture content } \\
\qquad\left(\mathrm{cm}^{3} \mathrm{~cm}^{-3}\right)\end{array}$} \\
\hline & $5 \mathrm{~cm}$ & $20 \mathrm{~cm}$ & $50 \mathrm{~cm}$ & $100 \mathrm{~cm}$ & & & \\
\hline \multicolumn{8}{|l|}{ Sundance, Wyoming } \\
\hline $08 / 5 / 2012$ & 0.137 & 0.162 & 0.289 & 0.428 & 0.753 & 0.960 & 0.280 \\
\hline $09 / 21 / 2012$ & 0.029 & 0.121 & 0.240 & 0.329 & 0.559 & 0.700 & 0.218 \\
\hline 07/31/2013 & 0.183 & 0.228 & 0.314 & 0.424 & 0.783 & 1.000 & 0.290 \\
\hline 08/16/2013 & 0.167 & 0.200 & 0.319 & 0.420 & 0.757 & 0.965 & 0.282 \\
\hline $09 / 17 / 2013$ & 0.153 & 0.261 & 0.362 & 0.409 & 0.683 & 0.866 & 0.258 \\
\hline $09 / 7 / 2015$ & 0.085 & 0.158 & 0.251 & 0.404 & 0.701 & 0.890 & 0.264 \\
\hline \multicolumn{8}{|l|}{ Lewistown, Montana } \\
\hline $07 / 04 / 2014$ & 0.101 & 0.186 & 0.185 & 0.144 & 0.245 & 0.279 & 0.170 \\
\hline $07 / 30 / 2014$ & 0.099 & 0.18 & 0.176 & 0.138 & 0.209 & 0.231 & 0.158 \\
\hline 08/9/2015 & 0.128 & 0.193 & 0.202 & 0.176 & 0.272 & 0.315 & 0.179 \\
\hline $08 / 25 / 2015$ & 0.105 & 0.183 & 0.193 & 0.165 & 0.251 & 0.287 & 0.172 \\
\hline
\end{tabular}
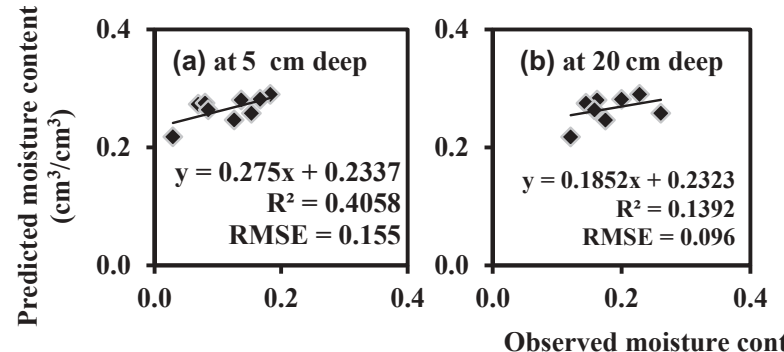

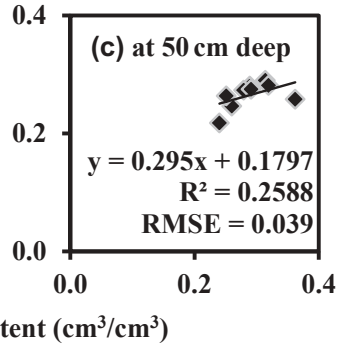

Figure 10. Comparison of the predicted and observed soil moisture content at Sundance, Wyoming.

\subsection{Validation of the estimated soil moisture at Lewistown, Montana}

The SERVES equation (Equation (12)) was used to estimate the soil moisture at the USCRN soil moisture measurement site at Lewistown, Montana, and the comparative analysis of the estimated soil moisture was performed for the entire growing season (JuneSeptember) for the years 2014 and 2015. The observed soil moisture data and NDVI data were obtained as described in Section 2.4. As for the Sundance study site, points (a) and (b) (Section 4.2) were considered in selecting the growing season NDVI images.

The soil type - clay loam - was identified from the NRCS SURRGO database, and the $\theta_{\mathrm{wp}}$ and $\theta_{\mathrm{fc}}$ were taken as 0.1 and 0.35 , as defined in Table 1 .
Table 3 presents the values of observed soil moisture at depths of 5,20,50 and $100 \mathrm{~cm}$, and the estimated soil moisture for the observed dates that match the satellite overpass dates. Likewise, Figure 11 shows the corresponding scatter plot of the observed versus calculated soil moisture mentioned in Table 3. Figure 11(a)-(d) presents the scatter plots of estimated versus observed soil moisture at depths of $5,20,30$ and $100 \mathrm{~cm}$, respectively, with $R^{2}$ values of 0.006 , $0.76,0.93$ and 0.76 , and RMSE of $0.056,0.016,0.019$ and 0.015 , respectively.

Similar to the RCEW and Sundance soil moisture measurement sites, the Lewistown site also showed that the best moisture prediction was in the depth range of $50-100 \mathrm{~cm}$, with the highest $R^{2}$ value of 0.93 at $50 \mathrm{~cm}$ depth and the lowest RMSE of 0.015 at $90 \mathrm{~cm}$ depth. 

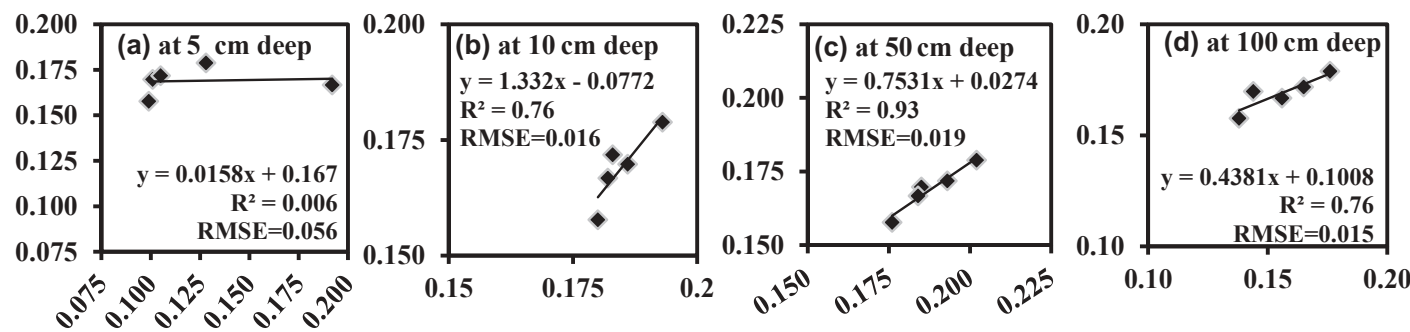

Observed moisture content $\left(\mathrm{cm}^{3} / \mathrm{cm}^{3}\right)$

Figure 11. Comparison of the predicted and observed soil moisture content at Lewistown, Montana.

\subsection{Effective root zone soil moisture representation}

It was shown in Sections 4.1-4.3 that the estimated soil moisture best represented the observed soil moisture at a depth of $50-100 \mathrm{~cm}$. The US Department of Agriculture Irrigation Guide (USDA 1997) shows that the effective root zone moisture extraction depth for most crops/vegetation is $60 \mathrm{~cm}$. The dominant land-cover vegetation type in the Reynolds Creek Experimental Watershed is sagebrush (Seyfried et al. 2000), and the effective root zone depth for sagebrush is approximately $90 \mathrm{~cm}$ (Rice 1984). Likewise, for the USCRN soil moisture sites (Sundance, Wyoming, and Lewistown, Montana), the land-cover vegetation type was identified as sedge/herbaceous and shrub/scrub. Crop roots do not extract water uniformly from the entire root zone. Thus, the effective root depth is that portion of the root zone where the crop extracts the majority of its water. Effective root depth is determined by vegetation type (USDA 1997, Jayawickreme et al. 2008). As the soil moisture estimation in this study was derived through a vegetation index-based evapotranspiration fraction, the soil moisture estimation proposed by the method presented herein was found to represent this effective root zone soil moisture.

Root zone soil moisture is a link between surface phenology and subsurface water storage; the change in root zone soil moisture is reflected by vegetation through biophysical processes (Rutter and Sands 1958). The NDVI has been widely used to indicate vegetation dynamics or growth (Piao et al. 2011, Donohue et al. 2013). It may be observed in the Appendix (Figs A1-A8) and Figures 10 and 11 that soil moisture patterns at deeper root zone soil depths were relatively stable compared to the near-surface soil profile, and this stable soil moisture pattern correlated well with the temporal persistence of the vegetation phenology spatial pattern. Therefore, the vegetation index-derived evaporative fraction effectively linked the root zone soil moisture inversion in this study.

\section{Summary and conclusion}

This study proposes a soil moisture retrieval method based on the relationship derived from satellite vegetation index-based evapotranspiration fraction, soil moisture properties, and soil moisture state.

The soil moisture retrieval procedure proposed in this study may be summarized as follows:
(1) The relationship between evapotranspiration fraction and vegetation index, NDVI, such as that defined by Equation (11) for the study region, provides distributed values of evapotranspiration fraction. Generalizing the evapotranspiration fraction and NDVI relationship at vastly different physiographic regions of the continental United States and beyond is left as future research work.

(2) The wilting point, $\theta_{\mathrm{wp}}$, and the field capacity, $\theta_{\mathrm{fc}}$, volumetric water content are obtained from a highresolution soil database using established pedotransfer functions that yield $\theta_{\mathrm{wp}}$ and $\theta_{\mathrm{fc}}$ as functions of soil texture (Rawls et al. 1982, 1983). High-resolution soil data at $30 \mathrm{~m}$ resolution are available globally. The NRCS SURRGO database covers the $30-\mathrm{m}$ soil database in the entire continental United States, while the National Geospatial-Intelligence Agency (NGA) provides global 30-m resolution soil-type information (Frankenstein et al. 2015).

(3) The SERVES equation (Equation (12)) estimates the distributed volumetric soil moisture values from distributed wilting point $\left(\theta_{\mathrm{wp}}\right)$ and field capacity $\left(\theta_{\mathrm{fc}}\right)$, and evapotranspiration fraction obtained from the sources mentioned in (1) and (2) above.

(4) Finally, employing the field capacity soil moisture condition for locations where the Temperature Vegetation Dryness Index (TVDI) is less than 0.2 , water bodies and underlying saturated areas are identified.

A multi-year verification of the retrieved growing season (June-September) soil moisture was performed with comparative analysis of observed conventional in situ point soil moisture measurements at the 239- $\mathrm{km}^{2}$ Reynolds Creek Experimental Watershed in Idaho (2006-2009) and the US Climate Reference Network soil moisture measurement sites in Sundance, Wyoming (2012-2015), and Lewistown, Montana (2014 and 2015). The proposed method best represented the root zone soil moisture condition with an average overall $R^{2}$ value of 0.72 and RMSE of 0.042 . This shows that the fineresolution $(30 \mathrm{~m})$ soil moisture estimation was successful at identifying the spatial variability of effective root zone moisture conditions in the study areas. The main advantages of using this soil moisture retrieval approach in this study were that:

- soil moisture can be estimated at a fine spatial resolution (e.g. 30-m grid resolution used in this study); 
- the method explicitly takes account of the soil moisture physical properties, such as field capacity and wilting point, in the soil moisture estimation formulation, making the method physically accountable;

- the method avoids ground-based auxiliary measurement data requirements in its physics-based simple formulation, thereby making it attractive for professional and non-professional use in similar data-scarce, ungaugedregions; and

- relatively stable soil moisture patterns at effective root zone soil depth correlated well with the temporal persistence of the vegetation phenology spatial pattern; therefore, the vegetation index-derived evaporative fraction effectively linked the root zone soil moisture inversion and not the rapidly fluctuating near-surface soil moisture.

In developing tools for water resource decision support (Hendrickx et al. 2015), the problem of data-sparse, ungauged basins has deemed a model formulation with reduced parameters necessary (Pradhan and Ogden 2010). The method used in this case study is simple, computationally straightforward and was found to be effective in estimating growing season root zone soil moisture.

Although, the root zone soil moisture identification approach demonstrated herein was derived on a physical basis, the NDVIbased $\mathrm{ET}_{\mathrm{rf}}$ is an empirical linear relationship whose parameters were found to be spatially distributed. Therefore, a probability density function approach was used to identify a likelihood parameter value from the samples within the study area. Even within a growing season, the probability density function of this parameter's values may differ from one arid/semi-arid region to another, due to changes in vegetation type and land use. How to take account of such changes in the probability density function of the empirical parameter values across similar climatic regions is for future research work.

In the growing season, water availability is critical for vegetation growth in arid and semi-arid regions. Therefore, the vegetation index reflected the change of root zone soil moisture, as demonstrated in this study. However, in a humid area, seasonal soil moisture content being significantly higher throughout, the vegetation index alone may not reflect the soil moisture spatial pattern effectively. Western et al. (2004) showed a significant correlation between the structure of the moisture pattern and topographic indices in humid catchments. In humid regions, topographically driven simple hydrological models, such as TOPMODEL (Beven and Kirkby 1979) and the OPM model (Pradhan and Ogden 2010), are effective in providing the spatial distribution of saturation conditions or soil moisture deficit. This study found no correlation between the topography and soil moisture in this arid/semi-arid study area. How to transition among the effective influences of vegetation index, topographic index and soil properties to identify the soil moisture under different climatic and physiographic regions is a broader regionalization topic, which requires subsequent investigation.

\section{Acknowledgments}

The USDA ARS Northwest Watershed Research Center and NOAA US Reference Climate Network (USCRN) are thanked for making and sharing the in situ soil moisture dataset. The constructive comments and valuable advice from Co-editor Ross Woods, Associate Editor Prashant Srivastava, reviewer Amen Al-Yaari at the National Institute of Agricultural Research, France, and an anonymous reviewer are greatly appreciated.

\section{Funding}

This research was partly supported by the US Army Military Engineering Program through work item number DBF8B0. Article Processing Charges (APCs) for the publication were supported by the US Army Corps of Engineers Flood and Coastal Storm Damage Reduction Research and Development Program.

\section{References}

Ahmad, M.U.D. and Bastiaanssen, W.G.M., 2003. Retrieving soil moisture storage in the unsaturated zone using satellite imagery and biannual phreatic surface fluctuations. Irrigation and Drainage Systems, 17 (3), 141-161. doi:10.1023/A:1025101217521

Allen, R.G., 2001. REF-ET: reference evapotranspiration calculation software for FAO and ASCE standardized equations. Kimberly, ID: University of Idaho, 82.

Allen, R.G., et al., 1998. Crop evapotranspiration, Guidelines for computing crop water requirements. Rome-Italy: FAO Irrigation and drainage paper, 56.

Allen, R.G., et al., 2005. The FAO-56 dual crop coefficient method for predicting evaporation from soil and application extensions. Journal of Irrigation and Drainage Engineering, 131 (1), 2-13. doi:10.1061/ (ASCE)0733-9437(2005)131:1(2)

Allen, R.G., Tasumi, M., and Trezza, R., 2007a. Satellite-based energy balance for mapping evapotranspiration with internalized calibration (METRIC): model. ASCE Journal of Irrigation and Drainage Engineering, 133 (4), 380-394.

Allen, R.G., Tasumi, M., and Trezza, R., 2007b. Satellite-based energy balance for mapping evapotranspiration with internalized calibration (METRIC): applications. ASCE Journal of Irrigation and Drainage Engineering, 133 (4), 395-406.

Allen, R.G., Tasumi, M., and Trezza, R., 2007c. METRIC ${ }^{t m}$, mapping evapotranspiration at high resolution, applications manual for landsat satellite imagery, version 2.0.3. Kimberly, ID: University of Idaho.

Anderson, M.C., et al., 2007. A climatological study of evapotranspiration and moisture stress across the continental United States based on thermal remote sensing: 1. Model Formulation. Journal of Geophysical Research, 112, D11112. doi:10.1029/12006JD007507

ASCE-EWRI, 2005. The ASCE standardized reference evapotranspiration equation. In: R.G. Allen, et al., eds. Standardization of reference evapotranspiration task committee final report. Reston, VA: Environmental and Water Resources Institute (EWRI) of the American Society of Civil Engineers, American Society of Civil Engineers (ASCE), 213 p.

Bagrov, N.A., 1953. 0 srednem mnogoletnem isparenij s poverchnosti sushi”. Meteorologiya i Gidrologiya, 10 (10), 20-25.

Baier, W. and Robertson, G.W., 1966. A new veraltile soil moisture budget. Canadian Journa of Plant Science, 46, 299-315.

Bastiaanssen, W.G.M., et al., 1998. A remote sensing surface energy balance algorithm for land (SEBAL): part 1. Formulation. Journal of Hydrology, 212-213, 198-212. doi:10.1016/S0022-1694(98)00253-4

Bell, J.E., et al., 2013. US Climate Reference Network soil moisture and temperature observations. Journal of Hydrometeorology, 14, 977-988. doi:10.1175/JHM-D-12-0146.1

Berg, A., et al., 2017. Soil moisture influence on seasonality and largescale circulation in simulations of the West African Monsoon. Journal of Climate, 30, 2295-2317. doi:10.1175/JCLI-D-15-0877.1 
Beven, K.J. and Kirkby, M.J., 1979. A physically based, variable contributing area model of basin hydrology. Hydrological Sciences Bulletin, 24, 43-69. doi:10.1080/02626667909491834

Brutsaert, W. and Sugita, M., 1992. Application of self-preservation in the diurnal evolution of the surface energy budget to determine daily evaporation. Journal of Geophysical Research, 97 (D17), 18377-18382. doi:10.1029/92JD00255

Budyko, M.I. and Zubenok, L.I., 1961. The determination of evaporation from the land surface. Izv. Ak. Nauk SSR, Se. Geog, 6, 3-17. in Russian.

Carlson, T., 2007. An overview of the "Triangle Method" for estimating surface evapotranspiration and soil moisture from satellite imagery. Sensors Journal, 7, 1612-1629. doi:10.3390/s7081612

Chafin, D.T. and Kimball, B.A., 1992. Ground-water geochemistry of the near-surface Wasatch formation, Northern Green River Basin, Sublette County, Wyoming. US Geological Survey. Denver, CO: U.S. Geological Survey. Water-resources investigation report, 91-4069.

Crago, R.D., 1996. Comparison of the evaporative fraction and the priestley-taylor a for parameterizing daytime evaporation. Water Resources Research, 32, 1403-1409. doi:10.1029/96WR00269

Donohue, R.J., et al., 2013. Impact of $\mathrm{CO}_{2}$ fertilization on maximum foliage cover across the globe's warm, arid environments. Geophysical Research Letters, 40, 3031-3035. doi:10.1002/grl.50563

Dorigo, W.A., et al., 2013. Global automated quality control of in situ soil moisture data from the International Soil Moisture Network. Vadose Zone Journal, 12. doi:10.2136/vzj2012.0097

Dyck, S., 1983. Overview on the present status of the concepts of water balance models. In: New Approaches in Water Balance Computations (Proceedings of the Hamburg, Workshop, August 1983). Wallingford, UK: International Association of Hydrological Sciences, IAHS Publ. no. $148,3-19$.

Eagleson, P.S., 1978. Climate, soil and vegetation. Water Resources Research, 14 (5), 705-776. doi:10.1029/WR014i005p00705

Feyisa, G.L., et al., 2014. Automated water extraction index: A new technique for surface water mapping using Landsat imagery. Remote Sensing of the Environment, 140, 23-35.

Fleming, K., Hendrickx, J.M.H., and Hong, S.-H., 2005. Regional mapping of root zone soil moisture using optical satellite imagery. Proceedings of International Society for Optical Engineering, SPIE, 5811, 159-170.

Frankenstein, S., Stevens, M., and Scott, C., 2015. Ingestion of simulated SMAP L3 soil moisture data into military maneuver planning. Journal of Hydrometeorology, 16, 427-440.

Glugla, G., 1980. Berechnung der realen Verdunstung im Modell JAC-A 75. In: S. Dyck, et al., ed. Angewandte Hydrologie;. Part 2, 2nd ed. Berlin, Germany: Verlag fur Bauwesen.

Gowda, P.H., et al., 2007. Remote sensing based energy balance algorithms for mapping ET: current status and future challenges. Transactions of the American Society of Agricultural and Biological Engineers, 50 (5), 1639-1644.

Hain, C.R., Mecikalski, J.R., and Anderson, M.C., 2009. Retrieval of an available water-based soil moisture proxy from thermal infrared remote sensing. Part I: methodology and validation. Journal of Hydrometeorology, 10, 665-683. doi:10.1175/2008JHM1024.1171

Hendrickx, J.M.H., et al., 2015. Benchmarking optical/thermal satellite imagery for estimation of evapotranspiration and soil moisture in decision support tools. JAWRA Journal of the American Water Resources Association, 52, 89-119. doi:10.1111/1752-1688.12371

Hill, R.W., 2002. Using evapotranspiration data to schedule irrigation of forages. In: Proceedings of 2002 Western Alfalfa and Forage Conference. Sparks, Nevada, Davis.

Holzman, M.E., Rivas, R., and Piccolo, M.C., 2014. Estimating soil moisture and the relationship with crop yield using surface temperature and vegetation index. International Journal of Applied Earth Observation, 28, 181-192.

Homer, C., et al., 2015. Completion of the 2011 National Land Cover Database for the conterminous United States - representing a decade of land cover change information. Photogrammatic Engineering and Remote Sensing, 81 (5), 345-354.
Hong, S., et al., 2016. Spatial variability of SEBAL estimated root-zone soil moisture across scales. International Journal of Remote Sensing, 37 (20), 4838-4853.

Hosseini, M. and Saradjian, M.R., 2011. Multi-index-based soil moisture estimation using MODIS images. International Journal of Remote Sensing, 32 (21), 6799-6809.

Jayawickreme, D.H., Van Dam, R.L., and Hyndman, D.W., 2008. Subsurface imaging of vegetation, climate, and root-zone moisture interactions. Geophysical Research Letters, 35, L18404. doi:10.1029/ 2008GL034690

Kamble, B., Kilic, A., and Hubbard, K., 2013. Estimating crop coefficients using remote sensing-based vegetation index. Remote Sensing, 5 (4), 1588-1602. doi:10.3390/rs5041588

Kang, Y., Khan, S., and Ma, X., 2009. Climate change impacts on crop yield, crop water productivity and food security - A review. Progress in Natural Science, 19, 1665-1674. doi:10.1016/j.pnsc.2009.08.001

Minhas, B.S., Parikh, K.W., and Srinavasan, T.N., 1974. Toward the structure of a production function for wheat yields with dated input of irrigation water. Water Resources Research, 10 (3), 383-393.

Mutiibwa, D. and Irmak, S., 2013. AVHRR-NDVI-Based crop coefficients for analyzing long term trends in evapotranspiration in relation to changing climate in the US High Plains. Water Resources Research, 49, 1-14. doi:10.1029/2012WR012591

Nicholson, S.E. and Farrar, T.J., 1994. The influence of soil type on the relationships between NDVI, rainfall and soil moisture in semiarid Botswana. II: NDVI response to Rainfall. Remote Sensing of the Environment, 50, 107-120.

Norero, A.L., 1969. A formula to express evapotranspiration as a function of soil moisture and evaporative demands of the atmosphere. Utah State University thesis.

Piao, S.L., et al., 2011. Changes in satellite-derived vegetation growth trend in temperate and boreal Eurasia from 1982 to 2006. Global Change Biology, 17, 3228-3239. doi:10.1111/j.1365-2486.2011.02419.x

Pradhan, N.R., et al., 2012. SEBAL evapotranspiration estimates for the improvement of distributed hydrologic model runoff and soil moisture predictions. In: C.M.U. Neale et al.eds, Remote Sensing and Hydrology (Proceedings of a symposium held at Jackson Hole, Wyoming, September 2010). Wallingford, UK: International Association of Hydrological Sciences, IAHS Publ. no. 352, 435-439.

Pradhan, N.R. and Ogden, F.L., 2010. Development of a one-parameter variable source area runoff model for ungauged basins. Advances in Water Resources, 33, 572-584. doi:10.1016/j.advwatres.2010.03.002

Rawls, W.J., Brakensiek, D.L., and Miller, N., 1983. Green-Ampt infiltration parameters from soils data. ASCE Journal of Hydrologic Engineering, 109 (1), 62-70.

Rawls, W.J., Brakensiek, D.L., and Saxton, K.E., 1982. Estimation of soil water properties. Transactions of the ASAE, 25 (5), 1316-1320.

Renger, M., Strebel, O., and Giesel, W., 1974. Beurteilung bodenkundlicher, kulturtechniseher und hydrologischer Fragen mit Hilfe von klimatischer Wasserbilanz und bodenphysikalischen Kennwerten. Zeitschrift für Kulturtechnik und Flurbereinigung, $15,148-160$

Rice, W.A., 1984. Preliminary two-dimensional regional hydrologic model of the nevada test site and vicinity. Albuquerque,New Mexico: Sandia National Laboratories, Report SAND83-7466.

Rutter, A.J. and Sands, K., 1958. The relation of leaf water deficit to soil moisture tension in Pinus sylvestris, L. 1. The effect of soil moisture on diurnal change in water balance. New Phytology, 57, 50-65.

Sandholt, I., Rasmussen, K., and Andersen, J., 2002. A simple interpretation of the surface temperature vegetation index space for assessment of surface moisture status. Remote Sensing of the Environment, 79, 213-224.

Sellers, P.J., 1985. Canopy reflectance, photosynthesis, and transpiration. International Journal of Remote Sensing, 6, 1335-1372.

Seyfried, M., et al., 2000. A geographic data-base for watershed research, Reynolds Creek Experimental Water-shed. Boise, ID: Northwest Watershed Research Center, US Department of Agriculture, Agricultural Research Service, Technical Bulletin NWRC 2000-3. 
Seyfried, M.S., et al., 2011. CZO Dataset: Reynolds Creek - Soil Moisture, Soil Evapotranspiration (1977-2011). Retrieved from http://critical zone.org/reynolds/data/dataset/[Accessed 15 January 2016]

Slaughter, C., et al., 2001. Thirty-five years of research data collection at the Reynolds Creek Experimental Watershed, Idaho, United States. Water Resources Research, 37 (11), 2819-2823.

Srivastava, P.K., et al., 2014. Remote sensing applications in environmental research. In: P.K. Srivastava, et al., ed. Society of Earth Scientists Series, Springer International Publishing Switzerland. doi:10.1007/978-3-319-05906-8_1

Tasumi, M., 2003. Progress in operational estimation of regional evapotranspiration using satellite imagery. Ph.D. dissertation. ID: Dept. Biological and Agricultural Engineering, University of Idaho.

Trezza, R., 2002. Evapotranspiration using a satellite-based Surface energy balance with standardized ground control. PhD dissertation. Logan, UT: Utah State University.

Tucker, C.J. and Sellers, P.J., 1986. Satellite remote sensing of primary production. International Journal of Remote Sensing, 7, 1395-1416.

USDA (US Department of Agriculture), 1997. National engineering handbook, part 652. Washington, DC: Irrigation Guide, Natural Resources Conservation Service.
USGS (US Geological Survey), 2017. Product Guide, Landsat surface reflectance derived spectral indices, Version 3.6. Washington, DC: Department of the Interior.

Welder, G.E., 1968. Ground-water reconnaissance of the Green River Basin, southwestern Wyoming. Washington, DC: US Geological Survey

Hydrologic Investigations Atlas, HA-290, scale 1:250,000, 2 sheets, 5 .

Western, A., et al., 2004. Spatial correlation of soil moisture in small catchments and its relationship to dominant spatial hydrological processes. Journal of Hydrology, 286, 113-134.

Xin, J., et al., 2006. Combining vegetation index and remotely sensed temperature for estimation of soil moisture in China. International Journal of Remote Sensing, 27, 2071-2075.

Zhai, K., et al., 2015. Comparison of surface water extraction performances of different classic water indices using OLI and TM imageries in different situations. Geo-Spatial Information Science, 18 (1), 32-42. doi:10.1080/10095020.2015.1017911

Zhang, L., Ji, L., and Wylie, B.K., 2008. Response of spectral vegetation indices to soil moisture in grasslands and shrublands. International Journal of Remote Sensing, 5267-5286. doi:10.1080/01431161.2010.496471 


\section{Appendix A}

Table A1. Observed and estimated soil moisture content at various depths at the Reynolds Creek Experimental Watershed (June 2006).

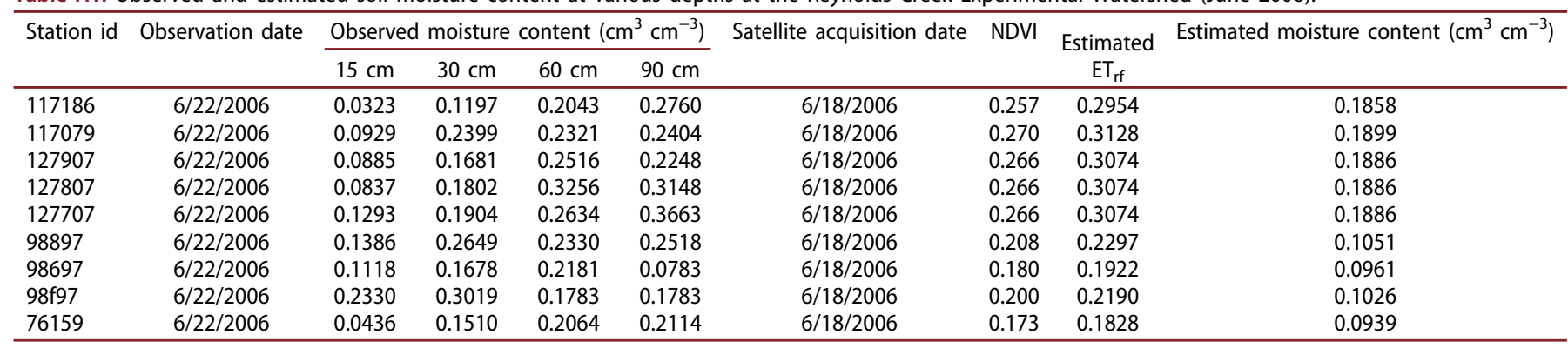

Table A2. Observed and estimated soil moisture content at various depths at the Reynolds Creek Experimental Watershed (July 2007).

\begin{tabular}{|c|c|c|c|c|c|c|c|c|c|}
\hline \multirow[t]{2}{*}{ Station id } & \multirow[t]{2}{*}{ Observation date } & \multicolumn{4}{|c|}{ Observed moisture content $\left(\mathrm{cm}^{3} \mathrm{~cm}^{-3}\right)$} & \multirow[t]{2}{*}{ Satellite acquisition date } & \multirow[t]{2}{*}{ NDVI } & \multirow{2}{*}{$\begin{array}{c}\text { Estimated } \\
\mathrm{ET}_{\mathrm{rf}}\end{array}$} & \multirow[t]{2}{*}{ Estimated moisture content $\left(\mathrm{cm}^{3} \mathrm{~cm}^{-3}\right)$} \\
\hline & & $15 \mathrm{~cm}$ & $30 \mathrm{~cm}$ & $60 \mathrm{~cm}$ & $90 \mathrm{~cm}$ & & & & \\
\hline 117186 & $7 / 11 / 2007$ & 0.0209 & 0.0925 & 0.1698 & 0.1890 & $7 / 7 / 2007$ & 0.170 & 0.1788 & 0.1587 \\
\hline 117079 & $7 / 11 / 2007$ & 0.0643 & 0.1467 & 0.2019 & 0.2104 & $7 / 7 / 2007$ & 0.161 & 0.1667 & 0.1559 \\
\hline 127907 & $7 / 11 / 2007$ & 0.0587 & 0.1371 & 0.2064 & 0.1861 & $7 / 7 / 2007$ & 0.171 & 0.1801 & 0.1590 \\
\hline 127807 & $7 / 11 / 2007$ & 0.0487 & 0.1361 & 0.2472 & 0.2385 & $7 / 7 / 2007$ & 0.171 & 0.1801 & 0.1590 \\
\hline 127707 & $7 / 11 / 2007$ & 0.0786 & 0.1315 & 0.2063 & 0.2397 & $7 / 7 / 2007$ & 0.171 & 0.1801 & 0.1590 \\
\hline 98897 & $7 / 11 / 2007$ & 0.0852 & 0.1963 & 0.1551 & 0.1895 & $7 / 7 / 2007$ & 0.120 & 0.1118 & 0.0768 \\
\hline 98697 & $7 / 11 / 2007$ & 0.0756 & 0.1292 & 0.1743 & 0.0660 & $7 / 7 / 2007$ & 0.126 & 0.1198 & 0.0788 \\
\hline 76159 & $7 / 11 / 2007$ & 0.0316 & 0.1342 & 0.1991 & 0.1957 & $7 / 7 / 2007$ & 0.141 & 0.1399 & 0.0836 \\
\hline $57 c 97$ & $7 / 11 / 2007$ & 0.0464 & 0.1217 & 0.0889 & 0.0803 & $7 / 7 / 2007$ & 0.133 & 0.1292 & 0.0810 \\
\hline $57 \mathrm{~h} 97$ & $7 / 11 / 2007$ & 0.0182 & 0.0981 & 0.1407 & 0.1125 & $7 / 7 / 2007$ & 0.127 & 0.1212 & 0.0791 \\
\hline 57896 & $7 / 11 / 2007$ & 0.0354 & 0.1384 & 0.1189 & 0.0912 & $7 / 7 / 2007$ & 0.134 & 0.1306 & 0.0813 \\
\hline
\end{tabular}

Table A3. Observed and estimated soil moisture content at various depths at the Reynolds Creek Experimental Watershed (August 2007).

\begin{tabular}{|c|c|c|c|c|c|c|c|c|c|}
\hline \multirow[t]{2}{*}{ Station id } & \multirow[t]{2}{*}{ Observation date } & \multicolumn{4}{|c|}{ Observed moisture content $\left(\mathrm{cm}^{3} \mathrm{~cm}^{-3}\right)$} & \multirow[t]{2}{*}{ Satellite acquisition date } & \multirow[t]{2}{*}{ NDVI } & \multirow{2}{*}{$\begin{array}{l}\text { Estimated } \\
\text { ET }_{\text {rf }}\end{array}$} & \multirow{2}{*}{$\begin{array}{l}\text { Estimated moisture content } \\
\qquad\left(\mathrm{cm}^{3} \mathrm{~cm}^{-3}\right)\end{array}$} \\
\hline & & $15 \mathrm{~cm}$ & $30 \mathrm{~cm}$ & $60 \mathrm{~cm}$ & $90 \mathrm{~cm}$ & & & & \\
\hline 117186 & $8 / 27 / 2007$ & 0.0510 & 0.0935 & 0.1714 & 0.1921 & $8 / 24 / 2007$ & 0.157 & 0.1607 & 0.1544 \\
\hline 117079 & $8 / 27 / 2007$ & 0.1383 & 0.1865 & 0.1893 & 0.2123 & $8 / 24 / 2007$ & 0.156 & 0.1600 & 0.1543 \\
\hline 127807 & $8 / 27 / 2007$ & 0.0477 & 0.1357 & 0.2545 & 0.2339 & $8 / 24 / 2007$ & 0.152 & 0.1547 & 0.1530 \\
\hline 127707 & $8 / 27 / 2007$ & 0.0780 & 0.1408 & 0.2054 & 0.2448 & $8 / 24 / 2007$ & 0.152 & 0.1547 & 0.1530 \\
\hline 98897 & $8 / 27 / 2007$ & 0.0722 & 0.1870 & 0.1551 & 0.1854 & 8/24/2007 & 0.120 & 0.1118 & 0.0768 \\
\hline 98697 & $8 / 27 / 2007$ & 0.0622 & 0.1333 & 0.1630 & 0.0678 & $8 / 24 / 2007$ & 0.136 & 0.1332 & 0.0820 \\
\hline 57c99 & $8 / 27 / 2007$ & 0.0386 & 0.1151 & 0.0860 & 0.0826 & $8 / 24 / 2007$ & 0.106 & 0.0930 & 0.0723 \\
\hline $57 \mathrm{~h} 99$ & $8 / 27 / 2007$ & 0.0151 & 0.0906 & 0.1403 & 0.1145 & $8 / 24 / 2007$ & 0.117 & 0.1078 & 0.0759 \\
\hline 57896 & $8 / 27 / 2007$ & 0.0289 & 0.1305 & 0.1185 & 0.0848 & $8 / 24 / 2007$ & 0.116 & 0.1064 & 0.0755 \\
\hline
\end{tabular}

Table A4. Observed and estimated soil moisture content at various depths at the Reynolds Creek Experimental Watershed (June 2008).

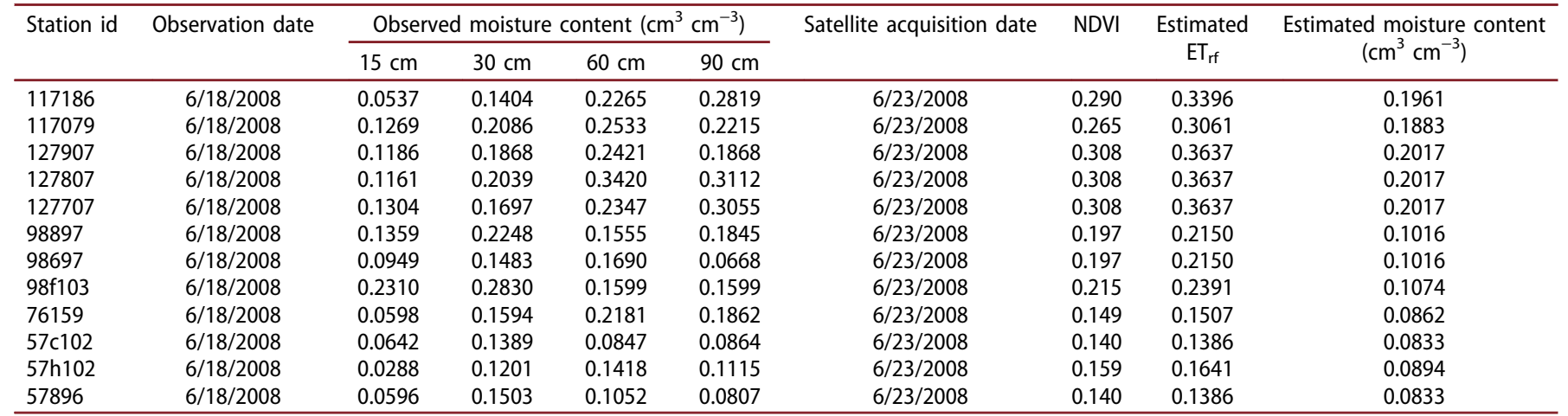


Table A5. Observed and estimated soil moisture content at various depths at the Reynolds Creek Experimental Watershed (July 2008).

\begin{tabular}{|c|c|c|c|c|c|c|c|c|c|}
\hline \multirow[t]{2}{*}{ Station id } & \multirow[t]{2}{*}{ Observation date } & \multicolumn{4}{|c|}{ Observed moisture content $\left(\mathrm{cm}^{3} \mathrm{~cm}^{-3}\right)$} & \multirow[t]{2}{*}{ Satellite acquisition date } & \multirow[t]{2}{*}{ NDVI } & \multirow{2}{*}{$\begin{array}{c}\text { Estimated } \\
\mathrm{ET}_{\mathrm{rf}}\end{array}$} & \multirow{2}{*}{$\begin{array}{l}\text { Estimated moisture content } \\
\qquad\left(\mathrm{cm}^{3} \mathrm{~cm}^{-3}\right)\end{array}$} \\
\hline & & $15 \mathrm{~cm}$ & $30 \mathrm{~cm}$ & $60 \mathrm{~cm}$ & $90 \mathrm{~cm}$ & & & & \\
\hline 117186 & $7 / 30 / 2008$ & 0.0246 & 0.0969 & 0.1792 & 0.1994 & $7 / 25 / 2008$ & 0.200 & 0.2190 & 0.1680 \\
\hline 117079 & $7 / 30 / 2008$ & 0.0678 & 0.1445 & 0.1988 & 0.2106 & $7 / 25 / 2008$ & 0.173 & 0.1828 & 0.1596 \\
\hline 127807 & $7 / 30 / 2008$ & 0.0551 & 0.1477 & 0.2671 & 0.2419 & $7 / 25 / 2008$ & 0.200 & 0.2190 & 0.1680 \\
\hline 127707 & $7 / 30 / 2008$ & 0.0928 & 0.1448 & 0.2060 & 0.2374 & $7 / 25 / 2008$ & 0.200 & 0.2190 & 0.1680 \\
\hline 98897 & $7 / 30 / 2008$ & 0.0958 & 0.1848 & 0.1551 & 0.1730 & $7 / 25 / 2008$ & 0.168 & 0.1761 & 0.0923 \\
\hline 98697 & $7 / 30 / 2008$ & 0.0709 & 0.1384 & 0.1702 & 0.0624 & $7 / 25 / 2008$ & 0.161 & 0.1667 & 0.0900 \\
\hline $57 c 103$ & $7 / 30 / 2008$ & 0.0391 & 0.1208 & 0.0877 & 0.0837 & $7 / 25 / 2008$ & 0.137 & 0.1346 & 0.0823 \\
\hline 57h103 & $7 / 30 / 2008$ & 0.0237 & 0.1031 & 0.1397 & 0.1128 & $7 / 25 / 2008$ & 0.132 & 0.1279 & 0.0807 \\
\hline 57896 & $7 / 30 / 2008$ & 0.0346 & 0.1328 & 0.1163 & 0.0894 & $7 / 25 / 2008$ & 0.131 & 0.1265 & 0.0804 \\
\hline
\end{tabular}

Table A6. Observed and estimated soil moisture content at various depths at the Reynolds Creek Experimental Watershed (August 2008).

\begin{tabular}{|c|c|c|c|c|c|c|c|c|c|}
\hline \multirow[t]{2}{*}{ Station id } & \multirow[t]{2}{*}{ Observation date } & \multicolumn{4}{|c|}{ Observed moisture content $\left(\mathrm{cm}^{3} \mathrm{~cm}^{-3}\right)$} & \multirow[t]{2}{*}{ Satellite acquisition date } & \multirow[t]{2}{*}{ NDVI } & \multirow{2}{*}{$\begin{array}{l}\text { Estimated } \\
\mathrm{ET}_{\text {rf }}\end{array}$} & \multirow{2}{*}{$\begin{array}{l}\text { Estimated moisture content } \\
\qquad\left(\mathrm{cm}^{3} \mathrm{~cm}^{-3}\right)\end{array}$} \\
\hline & & $15 \mathrm{~cm}$ & $30 \mathrm{~cm}$ & $60 \mathrm{~cm}$ & $90 \mathrm{~cm}$ & & & & \\
\hline 117186 & $8 / 13 / 2008$ & 0.0301 & 0.0942 & 0.1702 & 0.1957 & $8 / 10 / 2008$ & 0.175 & 0.1855 & 0.1464 \\
\hline 117079 & $8 / 13 / 2008$ & 0.0669 & 0.1526 & 0.2003 & 0.2139 & $8 / 10 / 2008$ & 0.167 & 0.1748 & 0.1437 \\
\hline 127807 & $8 / 13 / 2008$ & 0.0617 & 0.1514 & 0.2573 & 0.2463 & $8 / 10 / 2008$ & 0.184 & 0.1976 & 0.1494 \\
\hline 127707 & $8 / 13 / 2008$ & 0.0779 & 0.1346 & 0.1989 & 0.2284 & $8 / 10 / 2008$ & 0.184 & 0.1976 & 0.1494 \\
\hline 98897 & $8 / 13 / 2008$ & 0.0891 & 0.1934 & 0.1566 & 0.1781 & $8 / 10 / 2008$ & 0.142 & 0.1413 & 0.0925 \\
\hline 98697 & $8 / 13 / 2008$ & 0.0742 & 0.1473 & 0.1688 & 0.0759 & $8 / 10 / 2008$ & 0.146 & 0.1466 & 0.0937 \\
\hline $57 c 104$ & $8 / 13 / 2008$ & 0.0432 & 0.1184 & 0.0837 & 0.0837 & $8 / 10 / 2008$ & 0.134 & 0.1306 & 0.0900 \\
\hline 57h104 & $8 / 13 / 2008$ & 0.0171 & 0.1011 & 0.1404 & 0.1092 & $8 / 10 / 2008$ & 0.127 & 0.1212 & 0.0879 \\
\hline 57896 & $8 / 13 / 2008$ & 0.0391 & 0.1340 & 0.1109 & 0.0901 & $8 / 10 / 2008$ & 0.142 & 0.1413 & 0.0925 \\
\hline
\end{tabular}

Table A7. Observed and estimated soil moisture content at various depths at the Reynolds Creek Experimental Watershed (September 2008).

\begin{tabular}{|c|c|c|c|c|c|c|c|c|c|}
\hline \multirow[b]{2}{*}{ Station id } & \multirow[b]{2}{*}{ Observation date } & \multicolumn{4}{|c|}{ Observed moisture content $\left(\mathrm{cm}^{3} \mathrm{~cm}^{-3}\right)$} & \multirow[b]{2}{*}{ Satellite acquisition date } & \multirow[b]{2}{*}{$\mathrm{NDVI}$} & \multirow{2}{*}{$\begin{array}{c}\text { Estimated } \\
\mathrm{ET}_{\mathrm{rf}} \\
\end{array}$} & \multirow{2}{*}{$\begin{array}{l}\text { Estimated moisture content } \\
\qquad\left(\mathrm{cm}^{3} \mathrm{~cm}^{-3}\right)\end{array}$} \\
\hline & & $15 \mathrm{~cm}$ & $30 \mathrm{~cm}$ & $60 \mathrm{~cm}$ & $90 \mathrm{~cm}$ & & & & \\
\hline 117186 & $9 / 10 / 2008$ & 0.0518 & 0.1305 & 0.158 & 0.2065 & $9 / 11 / 2008$ & 0.149 & 0.15066 & 0.137 \\
\hline 117079 & 9/10/2008 & 0.0573 & 0.1355 & 0.1949 & 0.1982 & $9 / 11 / 2008$ & 0.14 & 0.1386 & 0.134 \\
\hline 127807 & $9 / 10 / 2008$ & 0.1395 & 0.1339 & 0.2496 & 0.2243 & 9/11/2008 & 0.148 & 0.14932 & 0.137 \\
\hline 127707 & 9/10/2008 & 0.0727 & 0.1339 & 0.1929 & 0.2266 & 9/11/2008 & 0.148 & 0.14932 & 0.137 \\
\hline 98897 & $9 / 10 / 2008$ & 0.0815 & 0.1977 & 0.1586 & 0.1878 & $9 / 11 / 2008$ & 0.148 & 0.14932 & 0.094 \\
\hline 57h105 & 9/10/2008 & 0.0451 & 0.1389 & 0.1356 & 0.1069 & $9 / 11 / 2008$ & 0.118 & 0.10912 & 0.085 \\
\hline 57896 & $9 / 10 / 2008$ & 0.0597 & 0.1429 & 0.1092 & 0.0766 & $9 / 11 / 2008$ & 0.117 & 0.10778 & 0.084 \\
\hline
\end{tabular}

Table A8. Observed and estimated soil moisture content at various depths at the Reynolds Creek Experimental Watershed (June 2009).

\begin{tabular}{|c|c|c|c|c|c|c|c|c|c|}
\hline \multirow[t]{2}{*}{ Station id } & \multirow[t]{2}{*}{ Observation date } & \multicolumn{4}{|c|}{ Observed moisture content $\left(\mathrm{cm}^{3} \mathrm{~cm}^{-3}\right)$} & \multirow[t]{2}{*}{ Satellite acquisition date } & \multirow[t]{2}{*}{ NDVI } & \multirow{2}{*}{$\begin{array}{c}\text { Estimated } \\
\mathrm{ET}_{\mathrm{rf}}\end{array}$} & \multirow{2}{*}{$\begin{array}{l}\text { Estimated moisture content } \\
\qquad\left(\mathrm{cm}^{3} \mathrm{~cm}^{-3}\right)\end{array}$} \\
\hline & & $15 \mathrm{~cm}$ & $30 \mathrm{~cm}$ & $60 \mathrm{~cm}$ & $90 \mathrm{~cm}$ & & & & \\
\hline 117186 & $6 / 25 / 2009$ & 0.21 & 0.28 & 0.25 & 0.31 & $6 / 26 / 2009$ & 0.324 & 0.38516 & 0.19629 \\
\hline 117079 & $6 / 25 / 2009$ & 0.2235 & 0.2792 & 0.2755 & 0.2406 & $6 / 26 / 2009$ & 0.318 & 0.37712 & 0.19428 \\
\hline 127807 & $6 / 25 / 2009$ & 0.2124 & 0.2847 & 0.3668 & 0.3374 & $6 / 26 / 2009$ & 0.332 & 0.39588 & 0.19897 \\
\hline 127707 & $6 / 25 / 2009$ & 0.2425 & 0.267 & 0.2927 & 0.3386 & $6 / 26 / 2009$ & 0.332 & 0.39588 & 0.19897 \\
\hline 98897 & $6 / 25 / 2009$ & 0.18 & 0.2492 & 0.1616 & 0.1892 & $6 / 26 / 2009$ & 0.216 & 0.24044 & 0.1153012 \\
\hline 98697 & $6 / 25 / 2009$ & 0.1916 & 0.1843 & 0.191 & 0.0795 & $6 / 26 / 2009$ & 0.2 & 0.219 & 0.11037 \\
\hline
\end{tabular}



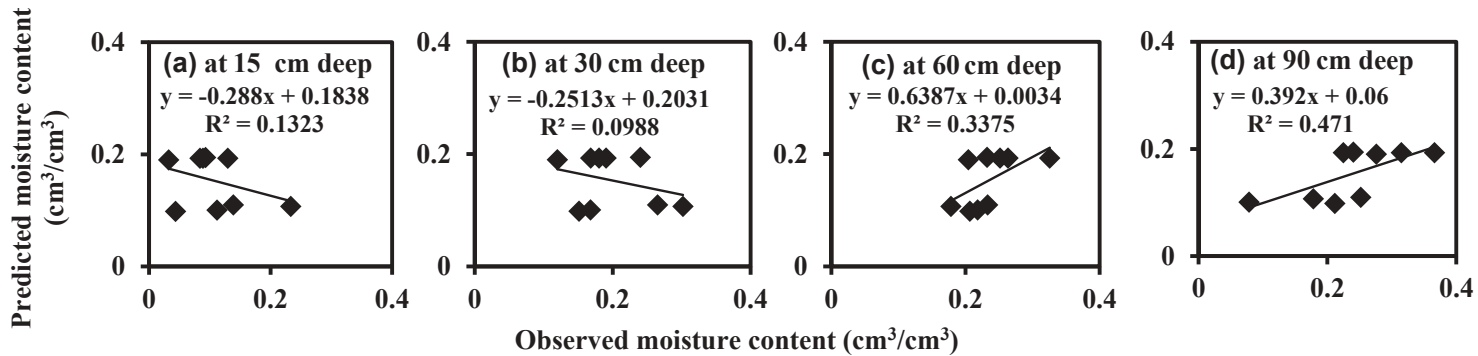

Observed moisture content $\left(\mathrm{cm}^{3} / \mathrm{cm}^{3}\right)$

Figure A1. Comparison of the predicted and observed (22 June 2006) soil moisture content in Reynolds Creek Experimental Watershed.
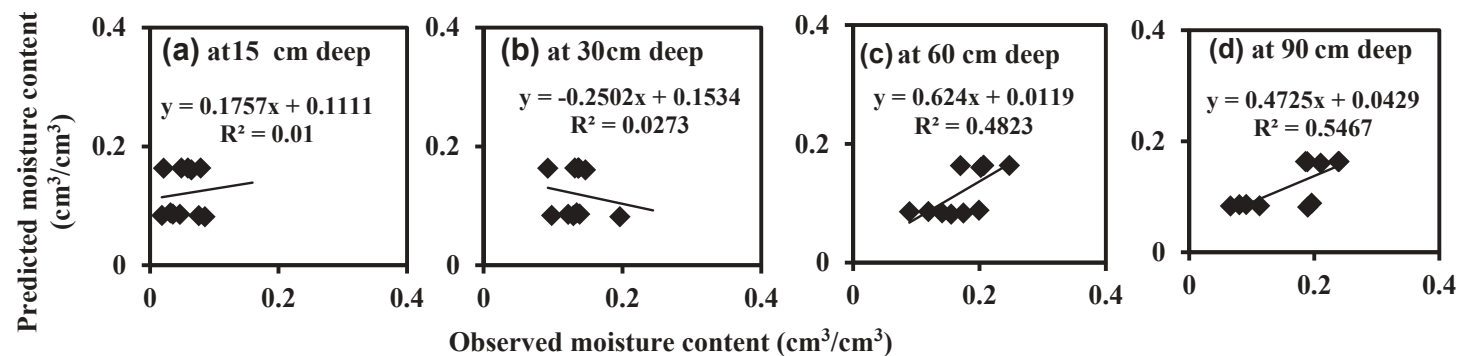

Figure A2. Comparison of the predicted and observed (11 July 2007) soil moisture content in Reynolds Creek Experimental Watershed.
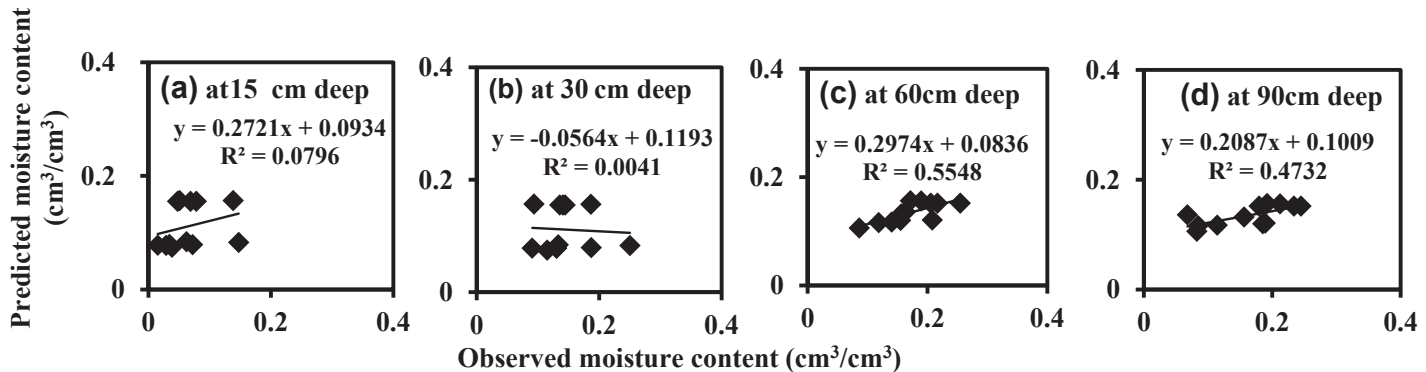

Figure A3. Comparison of the predicted and observed (27 August 2007) soil moisture content in Reynolds Creek Experimental Watershed.
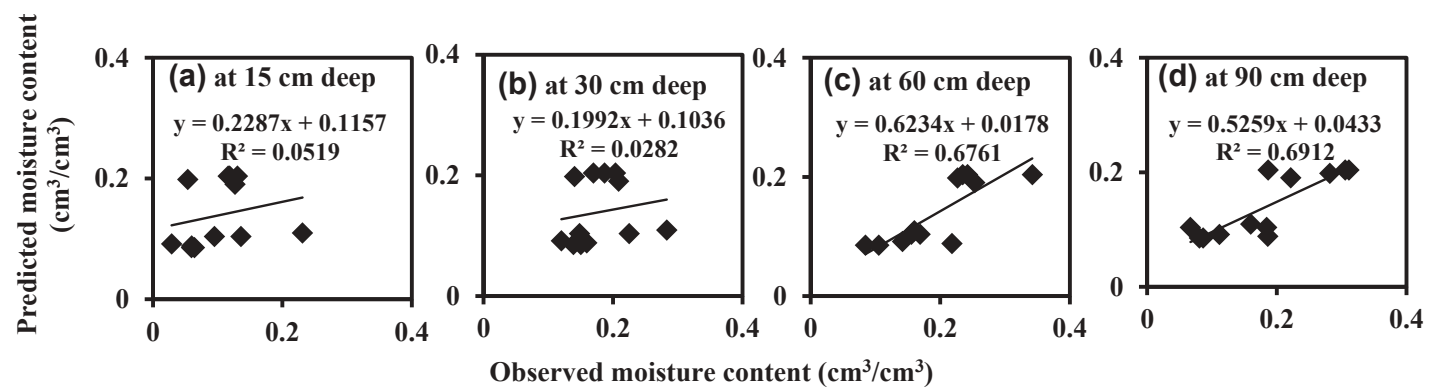

Figure A4. Comparison of the predicted and observed (18 June 2008) soil moisture content in Reynolds Creek Experimental Watershed. 

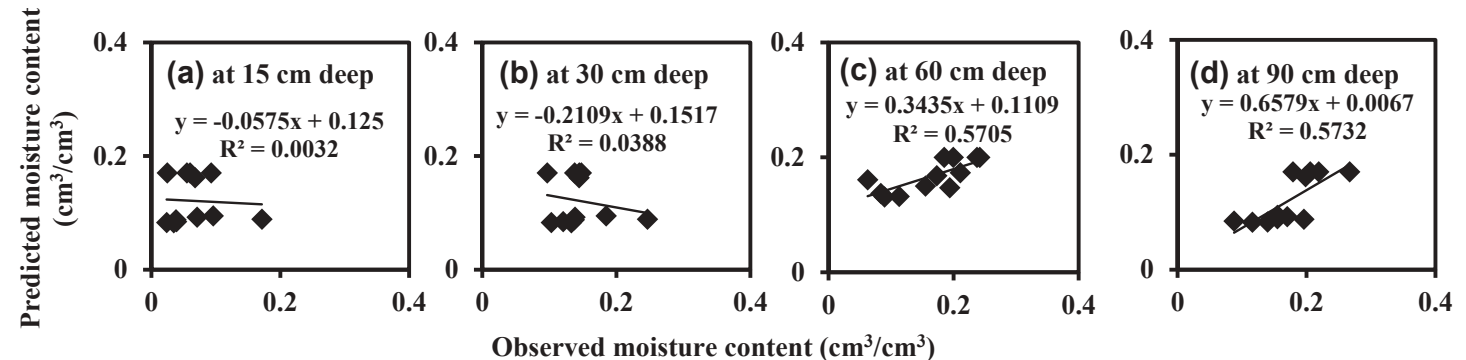

Figure A5. Comparison of the predicted and observed (30 July 2008) soil moisture content in Reynolds Creek Experimental Watershed.
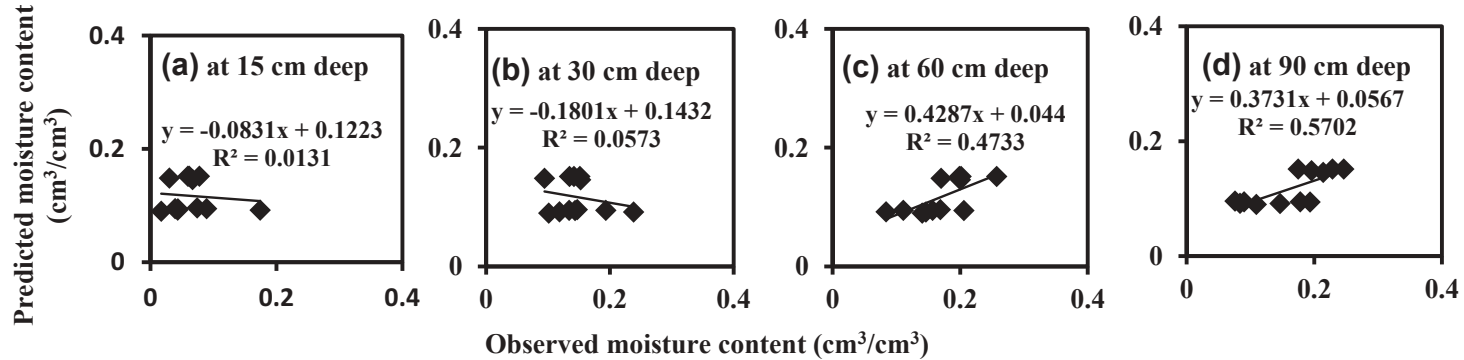

Observed moisture content $\left(\mathrm{cm}^{3} / \mathrm{cm}^{3}\right)$

Figure A6. Comparison of the predicted and observed (13 August 2008) soil moisture content in Reynolds Creek Experimental Watershed.
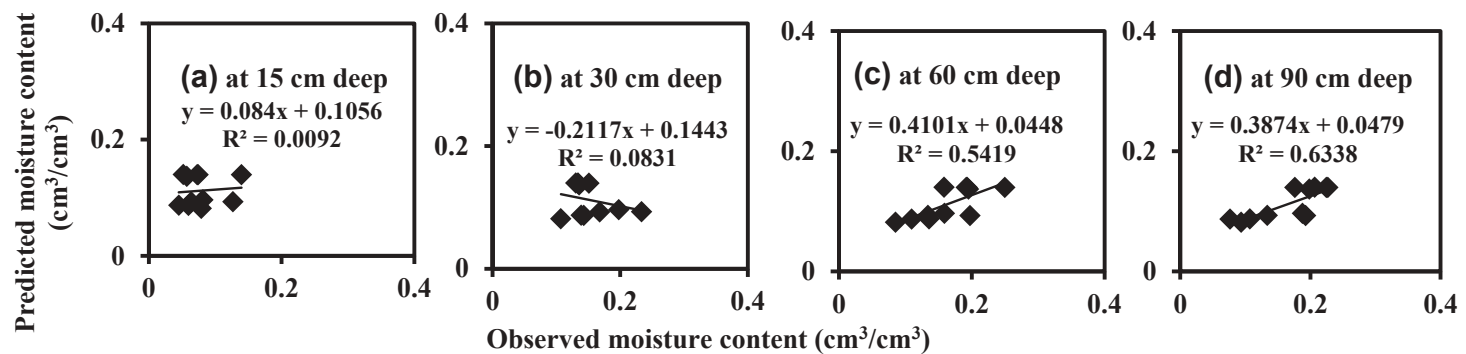

Figure A7. Comparison of the predicted and observed (10 September 2008) soil moisture content in Reynolds Creek Experimental Watershed.
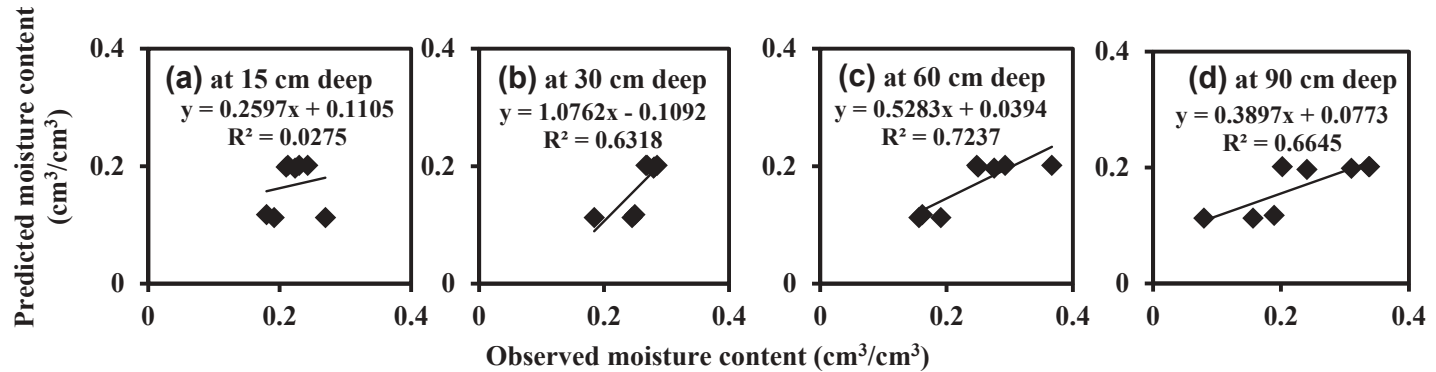

Figure A8. Comparison of the predicted and observed (25 June 2009) soil moisture content in Reynolds Creek Experimental Watershed. 


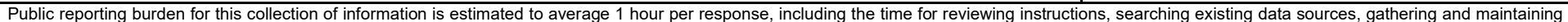

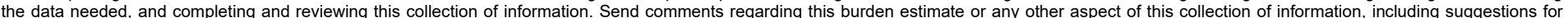

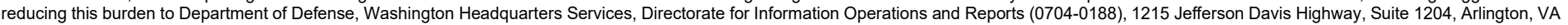

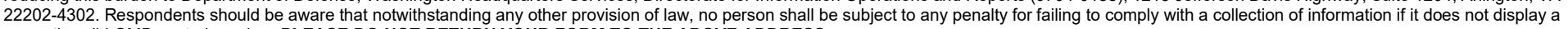
currently valid OMB control number. PLEASE DO NOT RETURN YOUR FORM TO THE ABOVE ADDRESS.
1. REPORT DATE (DD-MM-YYYY)
September 2021

\section{TITLE AND SUBTITLE}

Estimating growing-season root zone soil moisture from vegetation index-based evapotranspiration fraction and soil properties in the Northwest Mountain region, USA

\section{AUTHOR(S)}

Nawa Raj Pradhan

\section{PERFORMING ORGANIZATION NAME(S) AND ADDRESS(ES)}

Costal and Hydraulics Laboratory

U.S. Army Engineer Research and Development Center

3909 Halls Ferry Road

Vicksburg, MS 39180

9. SPONSORING / MONITORING AGENCY NAME(S) AND ADDRESS(ES)

U.S. Army Corps of Engineers

Washington, DC 20314

\section{DATES COVERED (From - To)}

\section{5a. CONTRACT NUMBER}

5b. GRANT NUMBER

5c. PROGRAM ELEMENT NUMBER

5d. PROJECT NUMBER

5e. TASK NUMBER

\section{5f. WORK UNIT NUMBER}

8. PERFORMING ORGANIZATION REPORT NUMBER

ERDC/CHL MP-21-6

10. SPONSOR/MONITOR'S ACRONYM(S)

11. SPONSOR/MONITOR'S REPORT NUMBER(S)

\section{DISTRIBUTION / AVAILABILITY STATEMENT}

Approved for public release; distribution is unlimited.

\section{SUPPLEMENTARY NOTES}

This article was originally published online in Hydrological Sciences Journal on 19 May 2019.

This research was supported by the US Army Military Engineering Program. Article Processing Charges (APCs) for the publication were supported by the US Army Corps of Engineers Flood and Coastal Storm Damage Reduction Research and Development Program.

\section{ABSTRACT}

A soil moisture retrieval method is proposed, in the absence of ground-based auxiliary measurements, by deriving the soil moisture content relationship from the satellite vegetation index-based evapotranspiration fraction and soil moisture physical properties of a soil type. A temperature-vegetation dryness index threshold value is also proposed to identify water bodies and underlying saturated areas. Verification of the retrieved growing season soil moisture was performed by comparative analysis of soil moisture obtained by observed conventional in situ point measurements at the 239-km2 Reynolds Creek Experimental Watershed, Idaho, USA (20062009), and at the US Climate Reference Network (USCRN) soil moisture measurement sites in Sundance, Wyoming (2012-2015), and Lewistown, Montana (2014-2015). The proposed method best represented the effective root zone soil moisture condition, at a depth between 50 and $100 \mathrm{~cm}$, with an overall average R2 value of 0.72 and average root mean square error (RMSE) of 0.042 .

\section{SUBJECT TERMS}

Effective root zone soil; moisture; satellite imagery; vegetation index; soil type; land surface temperature; evapotranspiration fraction

\section{SECURITY CLASSIFICATION OF:}

\section{a. REPORT}

Unclassified

\section{b. ABSTRACT}

Unclassified

\section{c. THIS PAGE}

Unclassified
17. LIMITATION OF ABSTRACT

UU
18. NUMBER OF PAGES

23 19a. NAME OF RESPONSIBLE PERSON

19b. TELEPHONE NUMBER (include area code) 